\title{
Mobile Application for Healthcare: The Case of COVID-19 in Mobile Apps
}

\author{
ROCCO REINA \\ rreina@unicz.it \\ University of Catanzaro
}

MARZIA VENTURA

marziaventura@unicz.it

University of Catanzaro

\author{
CONCETTA L. CRISTOFARO \\ concetta.cristofaro@unicz.it \\ University of Catanzaro
}

TERESA A.R. GENTILE

tgentile@unicz.it

University of Catanzaro

\begin{abstract}
The COVID-19 era has forced us to reduce our face-to-face interactions. For this reason, Information and Communication Technologies (ICTs) have substituted this direct relationship among people. One tool able to support health authorities by monitoring and mitigating the ongoing COVID-19 is Mobile Applications (mApps). They have also facilitated follow-up among patients and practitioners and provided direct guidance to citizens, so they can play their part in the control of the disease. The main purpose of this paper is to understand and analyse the features and functionalities of the COVID-19 mApps currently available in the widely used smartphone applications stores, such as Play Store and iTunes. The first results obtained at this stage of the research have permitted us to give a preliminary taxonomy of the mApps, specifically concerning COVID health management in Italy. The research found 71 mApps operating in the principal stores, focusing on the underlining features and aspects useful for making users more responsible and enabling self-management regarding their own health. MApps in the COVID period could represent organisational support for maintaining a useful relationship among patients and health operators concerning health care assistance. To do this, it is necessary to determine optimal capabilities and evaluate the utility and clinical benefit of these tools. Doing this, we have been able to recognise and obtain the first data and information through this research.
\end{abstract}




\section{Introduction}

The World Health Organization (WHO, 2011; Livingston and Bucher, 2020; Wu and McGoogan, 2020) has declared COVID-19 a pandemic outbreak. The Coronavirus pandemic has shown the importance of Information and Communication Technologies (ICTs) in a context in which "moving information" is much better than "moving people". In the pandemic context, where it's impossible to communicate with people face to face, ICTs have become the only tool able to substitute direct and personal relationships.

The COVID context has imposed, especially on the elderly, the need to develop ICT-related skills. At the same time, organisations face the need for using various mechanisms that facilitate and support interaction between individuals through ICT tools.

ICTs have demonstrated that they are a powerful tool that can aid the fields of healthcare by promoting patient empowerment and disease management. In this way, the mobile application can transmit information among health organisations, experts, families and people worldwide. Mobile Applications (mApps) can support health authorities - at the national and EU level (eHealth Network, 2020) - by monitoring and mitigating the ongoing COVID-19 pandemic, facilitating follow-up among patients and practitioners and providing direct guidance to citizens so that they can play their part in the control of the disease. With these premises, the spread of mobile applications represents a way health knowledge can be shared, improving the interactions between health operators and patients, and most likely the general efficient of processes. MHealth has great potential to address disruptive issues in healthcare, given the ubiquity of mobile devices around the world and the unique aspects of mobile technology, including its high reach, cost-effectiveness and relative ease tool use (Steinhubl et al., 2015). In addition, mHealth can link and interact patients with operating interfaces directly inside the App, frequently without the involvement of healthcare operators.

This possibility could generate new awareness regarding health and will indirectly impact on the costs related to the health system. So, mHealth represents a rapidly developing field which has the potential to play a critical role in the re-organisation of healthcare systems. This study focuses on the implementation and use of mobile devices to carry out or support health care activities remotely during the pandemic era. In fact, the COVID-19 situation has pushed for the development of new mApps able to support patients and communities in this complex period. Therefore, the main purpose of this work is to review and analyse the features and functionalities of the apps specifically dedicated to COVID-19 that are currently available in widely used smartphone application stores, like Play Store and iTunes.

The research questions are:

RQ1 What are the principal characteristics of mApps used for COVID-19?

$R Q 2$ Are mApps functional in regard to the objective?

RQ3 Are users' ratings proportionally linked to the functional content of $m$ Apps?

The study starts with a systematic examination of mApps for smartphones in the most popular mobile app stores in Google Play (for Androids) and the iTunes store (for macOS). The analysis of available mApps was conducted from February to April 2020, by selecting a 7 apps from the Play Store and 64 from iTunes. The present work is structured as follows: section 1 is the introduction, followed by the theoretical background in section 2, methodology and 
data selection in section 3, Results and Discussion in sections 4, and, finally, conclusions and organisational Implications in section 5.

\section{Theoretical background}

Several scholars claim that the application of Knowledge Management (KM) practices in the healthcare sector is a growing research area. Healthcare organisations are an institutional and social model that represent a complex organisational environment. Traditional KM practices in health care organisations did not seem consistent with their institutional goals; in fact, the adoption, transfer and sharing of new knowledge in healthcare organisations requires different methods and techniques. $\mathrm{KM}$ is a process, according to scholars, and the existing literature offers a large number of KM processes (Gao et al., 2018). The operational definition of $\mathrm{KM}$ focuses on three processes: knowledge creation, knowledge sharing (KS) and knowledge utilisation (Shujahat et al., 2019). Many scholars have pointed out that KS is a key pillar for effective KM (Alavi and Leidner, 2001; Donnelly, 2019). KS refers to the "process of sharing relevant information, ideas, suggestions and skills with others" (Bartol and Srivastava, 2002: 65), as well as the "process in which individuals exchange their knowledge (explicit and implicit) and create new knowledge" (Van den Hooff and De Ridder, 2004: 118). A significant number of previous studies have explored KS through the meso-level lens, emphasising the role of ICT systems in KS (Mirzaee and Ghaffari, 2018). However, attention was dedicated to what practitioners mean by KS and, more specifically, how they exchange knowledge in practice (Minbaeva, 2013; Panahi et al., 2016; Donnelly, 2019). Hence, users use information and communication technologies (ICTs) to share tacit and explicit knowledge among organisation members and external parties (Panahi et al., 2016; Bouncken and Aslam, 2019). Since the IT tools make KS easy (Ghosh and Scott, 2005), according to Salisbury and Bloodgood (2001), IT has two main capabilities with respect to knowledge, namely, to encode knowledge and create networks. Therefore, IT facilitates interaction among people and ultimately improves the KS. Furthermore, IT makes knowledge clearer and more explicit, as modern technologies make it easier to encode knowledge by making it available (Salisbury and Bloodgood, 2001). The ability of IT to encode knowledge and make it more explicit is significant (Salisbury and Bloodgood, 2001). There are several types of IT tools used in KS, like the intranet, chat, email, blog, etc. (Omana et al., 2010). Depending on the types of knowledge, IT is designed for KS practices. Within the use of IT in healthcare, Mobile Health (mHealth) is highlighted and defined by Istepanian et al. (2007) as the use of "emerging mobile communications systems and network technologies for healthcare". A more comprehensive definition is implemented by the World Health Organization (WHO, 2011: 6) which defines mHealth as "medical and public health practices supported by mobile devices, such as mobile phones, patient monitoring devices, personal digital assistants and other wireless devices". The adoption of these technologies in healthcare has allowed the transition from Electronic Health (e-Health) systems of traditional "telemedicine" platforms to wireless communication and wireless and mobile configurations (Istepanian et al., 2007). Basically, using mobile devices connected through the network and wireless communication technology in healthcare improves health safety and results (Yu et al., 2006), overcoming geographical, temporal and even organisational barriers with low costs and convenient practices (Silva et al., 2015).

In this new evolving context, a particular role is played by apps (on mobile devices), as a new technological system capable of transmitting, creating and sharing knowledge and improving 
an open innovation model (Chesbrough, 2003). MApps is an interactive tool among patients and doctors, capable of facilitating the monitoring and highlighting of alarms by developing combinations of know-how among the nodes of healthcare networks.

The use of mobile applications (mApps) in healthcare provides three clarifications.

First of all, each user/patient can use mobile applications (mApps) in healthcare that are downloadable through the main operating systems existing on smartphones and mobile phones (Apple iOS, Android and others). However, this can only happen if these four main characteristics are attainable (Davis et al., 2016): (1) population penetration or adoption, (2) the availability and form of apps, (3) the availability and form of wireless broadband Internet access; and (4) individual ownership of the device. The first feature is an internet connection (e.g., coverage, service continuity, reduced connectivity delays). The second feature of smartphone technology is the availability of apps that can be installed on the device. The third feature is the ability to quickly access the Internet or the World Wide Web via mobile broadband. The last feature of the technology is that cell phones are usually in people's possession; they are associated with individuals, not residences (which require a permanent physical location).

Secondly, ICT and medical experts can combine their knowledge to produce innovative and user-friendly mApps. Patients as users - on the other hand-can learn new information on how to prevent and treat their disease, even if the mApp is not connected with healthcare professionals (Kogut and Zander, 1992). According to the Institute for Healthcare Informatics (IIHF, 2013), consumer-related mHealth apps focus on general wellbeing, diagnosis, finding a healthcare provider, filling prescriptions and compliance. Dennison et al. (2013) conducted a qualitative study on young adults to explore their experiences and positions regarding apps related to health behaviour change, including their perception of various characteristics and their willingness to use the apps. They identified several valuable features that have major influences on the usability of the app, such as: accuracy, legitimacy, security, required effort and immediate effects. Interestingly, context sensing capabilities and social media features were deemed unnecessary. However, they also noted that some of their study participants weren't motivated enough to regularly and accurately use apps to make healthy lifestyle changes. This phenomenon is particularly relevant in immersive online virtual worlds that offer new territories that can often be customised by users and where rules and fees become more labile (Taylor, 2002).

Third, the dissemination and ease of downloading of mApps represent a way in which healthcare professionals and patients/users can better share health knowledge (KS) and can provide adequate tools to support this (Atinaf and Garfield, 2015). On the one hand, the motivations to carry out KS through Apps in healthcare would be attributable to the selfefficacy and personal development of the operators and users/patients who use them (Zhang et al., 2017; Choi et al., 2020).

On the other hand, the sharing of knowledge implemented through mHealth leads to greater interaction among healthcare professionals and patients and greater efficiency (Eze et al., 2016). In fact, there is a reduction and improvement in terms of patient data collection by healthcare professionals, allowing for easier storage of this information in a shared way.

For this reason, the first phase of the study aimed to understand the main theories in this research area. This step is necessary due to the exploratory nature of the study. In particular, the keywords were entered through the consultation of databases. A search string was created 
to identify all scientific documents in English, published in double-blind journals and belonging to the Business, Management and Accounting areas. After this selection, a focus on a systematic review of the phenomenon was carried out by VOS viewer as a software tool for constructing and visualising bibliometric networks. Figure 2.1 shows the relationship between the keywords that the authors used for their scientific contributions. Each circle represents a keyword. The size of a circle reflects the number of publications of the corresponding word. The distance between two circles approximately indicates the strength of the link. In general, the closer two circles are located to each other, the stronger the link is among keywords. The colours represent clusters of keywords with strong links. Lines are used to indicate the links between keywords.

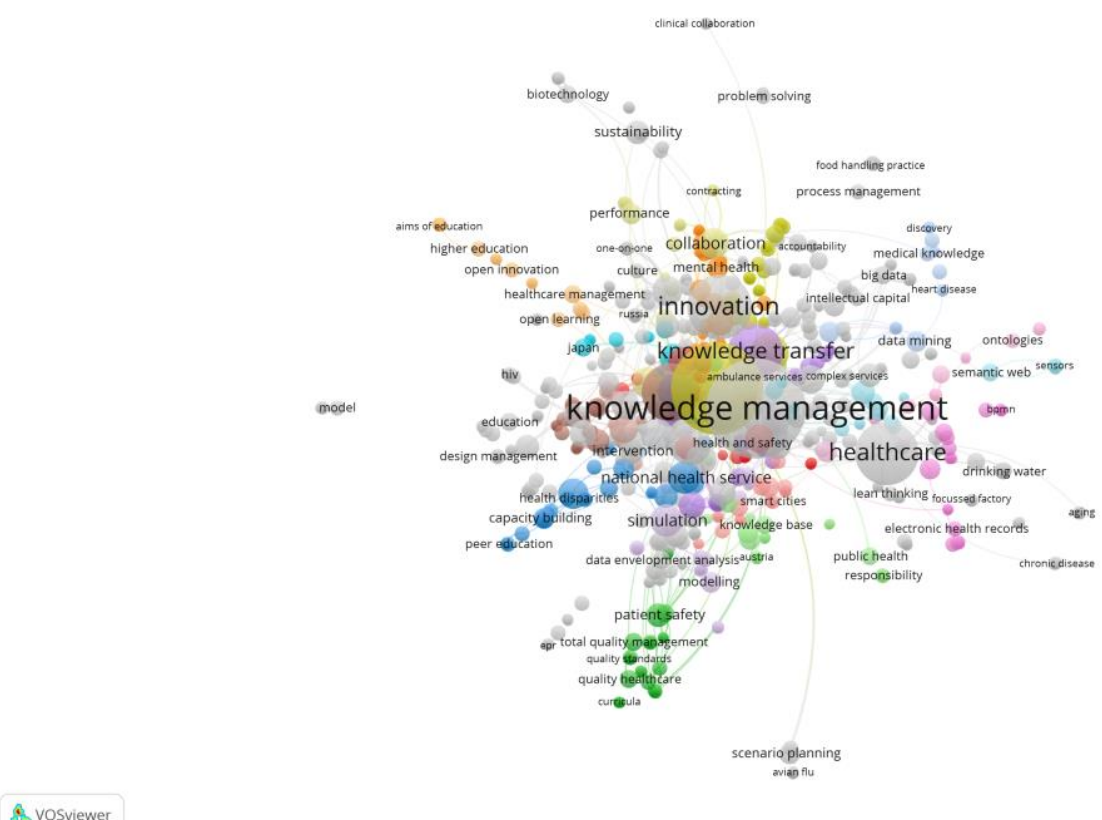

Figure 2.1. Relationship between keywords - VOS viewer Software.

From Figure 2.1, it is clear that this new phenomenon of mApps in healthcare has created a solid framework in the KM field of study. The selection of the sub-area keywords highlights how the mApps phenomenon, studied under the KM perspective, is linked to: Knowledge Management, Knowledge Transfer, Innovation, Open Learning, Health Care Management, Higher education and Culture. 


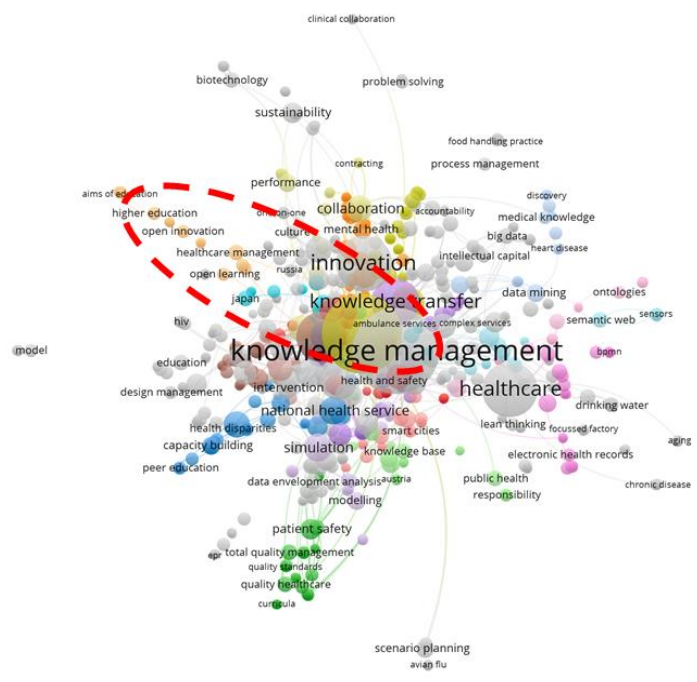

Figure 2.2. Sub-area keywords - Our Elaboration with VOS viewer Software.

Therefore, it is possible to identify, within the graph, one research area that links the topics covered in this study (Figure 2.2).

\section{Methodology and data selection}

This work presents the results of the exploratory and descriptive study to understand and define the frame of the general dynamics of the phenomenon $[7 ; 24 ; 17]$ This study is based on a two-step method:

The first step-Theoretical Background-explores the literature and underlines the characteristics of the mApps as a new mechanism of sharing knowledge in Healthcare. In this step, on the desk, analysis scientific documents were identified and filtered by using keywords, language and abstract.

For this reason, a review of the literature was conducted in April 2020 by the author. The systematic review was completed in accordance with the Preferred Reporting Items for Systematic Review and Meta-Analyses (PRISMA) guidelines (PRISMA, 2009). However, this protocol was modified by incorporating the article screening process as each article was identified, rather than as a single solitary stage later on its process. The search strategy used a series of specific keywords. A primary keyword (1 - Knowledge Management) was used in direct combination with a second (2 - Knowledge Sharing) and third keyword (3 - IT), and 4 mobile Application (mApp).

Four inclusion criteria were established to exist as a specification for relevance once any sources were identified. The four criteria were:

1) The years considered must be between 2014 and 2020;

2) Must be peer-reviewed literature;

3) English language;

4) Open access. 
Relevant bibliographic databases were used for this purpose, including the Scopus databases. Furthermore, referring to PRISMA protocol, additional records were identified through other sources. These sources included the use of article reference lists identified through the primary search stage by using Google Scholar. Once the duplicates had been removed, the remaining publications were then filtered using the inclusion criteria.

\begin{tabular}{|l|l|}
\hline Number of articles from the first search & 498 \\
\hline $\begin{array}{l}\text { Number of articles removed due to article duplication/application of eligibility } \\
\text { criteria }\end{array}$ & 30 \\
\hline Number of eligible articles from the first search & 458 \\
\hline Number of those eligible after reading the abstract & 135 \\
\hline Number of those eligible after reading the full paper & 36 \\
\hline Number of articles identified by other means & 2 \\
\hline Total number of eligible articles & 38 \\
\hline
\end{tabular}

Table 3.1. PRISMA protocol.

Source: Our elaboration.

Subsequently, 38 publications met the conditions and were included in this review, allowing us to frame the phenomenon theoretically in according to the research questions.

The second step-Empirical Observation - - firstly explores the different mApps officially identified as COVID-19 tools and presents the most popular operating platform (Play Store and iTunes). Then, we classified mApps according to their Type, Technical functionality, Description, Download and Users comment. In this way, it was possible to comprehend the aspects of knowledge and the possibility of sharing and diffusion (see Table I.1 in Appendix).

In this phase, we had to consider both payment and free mApps found in the Play Store and iTunes app store (Figure 3.1). Until April 28, 2020, Android and macOS users could choose among $71 \mathrm{mApps}$. Our search focused on COVID-19 management, prevention, contact tracing mApps, using search terms such as: "COVID-19 and Coronavirus". In the following scheme, the research-mApp-process is presented. 


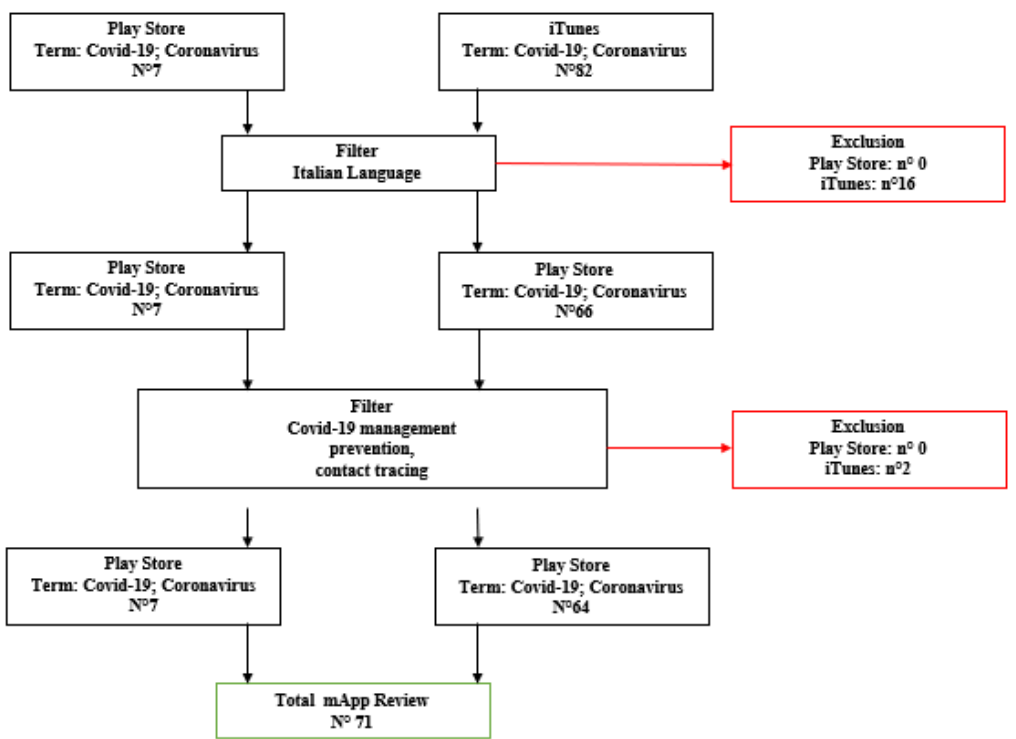

Figure 3.1. Examination scheme of mApps; Source: our elaboration on Moher et al. (2009).

Then the mApps were evaluated through a review based on product description, technical functionality and the screenshots provided with the reviews by current users. All data were collected in an Excel sheet, with the name, functionality and features of each mApp.

\section{Results and discussion}

Since the beginning of the COVID-19 pandemic, numerous mApps have been developed, some by public authorities like World Health Organization (WHO, newsletter March 2020), Italian Ministry of Health, Ministry of Social Affairs, Ministry of Communication; Governments and Departments. They have worked on the development of applications able to provide medically approved information and advice to users based on their symptoms.

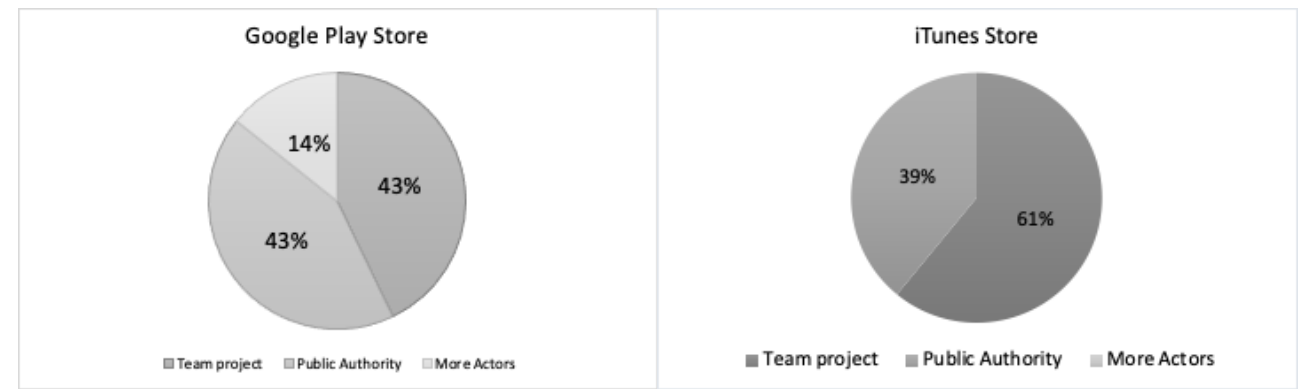

Figure 4.1. Section Actor Relevant.

Source: our elaboration

On April 10, 2020, Google and Apple jointly announced an initiative related to the use of the Bluetooth protocol to support contact tracing mApps (Newsroom-Apple, 2020). 
The protocol supports the use of Bluetooth LE (Low Energy) for the detection of nearby mobile phones and the data exchange mechanism. In this way, mApp users can receive an alert of possible Coronavirus transmission, by showing people with a positive diagnosis that they have recently been in contact with. The apps included in the present study are those pertaining to COVID-19 and are available in Google Play and the iTunes Stores. Our research started with keywords like "COVID-19 and Coronavirus", detecting 71 mApps (Google play store and iTunes store); once identified, manual inspection was done on the apps by using the filters: management and prevention contact tracing. As a result, $7 \mathrm{mApps}$ in the Google Play Store and 64 in the iTunes Store were found.

The research led to mApps, according to the previous criteria, $\mathrm{n}^{\circ} 71 \mathrm{mApps}$ overall. The differences between the Google Store and Apple Store are remarkable for different reasons, and the research on the Play Store showed only $7 \mathrm{mApps}$ unlike the initial 82 in iTunes, all this to ensure the credibility of health and safety information related to mApps. Apple has chosen to manage applications related to the COVID-19 pandemic with a very critical review by reviewing the publishing policies aimed at developers for apps. Google, to avoid problems, blocked mApps in March and subsequently publishes only 7 of them.

The overall characteristics of the mApps selected are presented in the tables in the Appendix; the analysis was developed by the authors directly through their phone. In fact, mApps are designed to interact directly with users with the acquisition of personal information to manage their own health, with or without the presence of a health worker. In this research, $71 \mathrm{mApps}$ were able to support patients with a pro-active approach by improving their participation and self-management capacity with self-monitoring programs (see Table 4.1).

In this research, the $71 \mathrm{mApps}$ identified are mostly related to the detection and contact warnings, self-diagnosis or the transfer of information and knowledge and symptom control.

\begin{tabular}{|l|l|l|l|}
\hline \multirow{4}{*}{} & $\begin{array}{l}\text { Symptom checking and contact } \\
\text { tracing }\end{array}$ & Play Store (Android) & iTunes Store (macOS) \\
\cline { 2 - 4 } Type & \begin{tabular}{l} 
Contact tracing and self-diagnosis \\
\cline { 2 - 4 }
\end{tabular} & 3 & 2 \\
\cline { 2 - 5 } & Contact Tracing and warning & 1 & 22 \\
\cline { 2 - 5 } & $\begin{array}{l}\text { Knowledge transfer } \\
\text { Contact Tracing, warning and self- }\end{array}$ & 1 & 15 \\
\cline { 2 - 5 } & Contact Tracing and information & 0 & 2 \\
\cline { 2 - 5 } & Guidelines & 0 & 1 \\
\cline { 2 - 5 } & Contact tracing and prevention & 0 & 1 \\
\hline & Job security & 0 & 1 \\
\hline
\end{tabular}

Table 4.1. Section Type. 
Source: our elaboration.

The main purposes of this work are to give answers regarding the three Research Questions proposed (RQ1-RQ2-RQ3). At this point of the analysis, the contribution presents the survey produced during this COVID period with the full list of existing mApps and their principal characteristics, as reported in tables (see the tables in Appendix). Every mApp has its own specific goals and technical characteristics, such as the minimum number of clicks, taps or other user gestures to activate themselves by responding in a fast and rapid way to the interactions requested.

One of the principal characteristics of mApps investigated is their simple design, able to ensure good content, high value and acceptance among users. A lot of mApps are responsive when running long operations such as database access and network access (users' comment). Another feature regards mApps' personalisation through the creation of individual content and roles based on the context or their specific usage. In fact, users want the mApp to fit their needs and perform the way they want it to. This specific attribute not only covers custommade content but also controls data that is stored, shared or used for different actions. The mApps have sensors that respond to device movement, numerous gestures, a global positioning system, cameras and multiple networking protocols. About $30 \%$ of the selected mApps show localised information and the possibility to provide their position. Information is a crucial feature that renders mobility impressive, convenient and valuable by providing a good user experience. So, their reachability permits us to use them anywhere, at any time (100\% mapping). The $\mathrm{m}$-Apps can send and receive and record Bluetooth signals even in the background mode (even when the phone is locked) and can estimate, with sufficient accuracy, the proximity among mobile phones via Bluetooth signals. They make their presence known continuously by using a temporary anonymous ID that permits established contact with other App users in proximity. The App records and stores IDs observed from other mobile phones in epidemiologically relevant proximity on the device, and then the App communicates this information to a Public Health Authority. Another important feature is security; around 20\% of the comments found by users ask for a secure mobile app. They believe that these problems should be rectified because they think that mobile apps are vulnerable. In fact, with the interactive knowledge-transfer platform, vital parameters can be acquired and monitored and subsequently sent to health organisations. In this way, users can record significant information about the virus; it is important and practical to record routine activities and medical care received and keep track of the progress of the disease. As a result, it is possible to indicate accelerated or delayed growth of the virus. Users can also use the diary and recording features. Likewise, keeping the mApp on your person is important to evaluate and detect eventual diagnosis discomforts.

Furthermore, the healthcare workforce can be more efficient and virtually close to patients, supported by real-time communication with them (e.g., via the exchange of app users' data). In addition, the possibility to share experiences with others can be of great assistance in addressing certain issues about manage and social relationship. Social support can reduce levels of stress as well as improve our overall health and quality of life. Secure and easy-to-use mHealth apps have the potential to increase adherence and engagement with the health system as a whole. The last characteristic is usability; it relates to the ease with which users can complete their tasks in a specified context of use (comments by the users). 
The task structure and interaction style should be optimal to minimise usability flaws. The purpose of the development of the mApp for COVID-19 is to limit the infection, manage the monitoring and self-management of the virus, etc. In this study, we considered whether mApps were functional in regard to the objective. $70 \%$ of mApps has the function to reliably determine the epidemiologically targeted, so the information on App should be able to estimate, with sufficient accuracy, the proximity to the "contagion risk map". $30 \%$ of mApps has the function of acquiring and monitoring vital parameters and subsequently sending them to health organisations.

\begin{tabular}{|l|l|l|l|}
\hline \multirow{5}{*}{$\begin{array}{l}\text { Technical } \\
\text { Functionality }\end{array}$} & Play Store (Android) & $\begin{array}{l}\text { iTunes Store } \\
\text { (macOS) }\end{array}$ \\
\cline { 2 - 4 } & Proximity technology & 5 & 56 \\
\cline { 2 - 4 } & $\begin{array}{l}\text { Interactive knowledge-transfer } \\
\text { platform }\end{array}$ & 1 & 1 \\
\cline { 2 - 4 } & $\begin{array}{l}\text { Acquisition and monitoring of vital } \\
\text { parameters }\end{array}$ & 1 & 6 \\
\cline { 2 - 4 } & $\begin{array}{l}\text { Invention management in the } \\
\text { Region }\end{array}$ & 0 & 1 \\
\hline
\end{tabular}

Table 4.2. Technical Functionality.

Source: our elaboration.

\section{Conclusions and organisational implications}

The results of this study show that mApps have great ability to engage users (patients) in the healthcare process, which is mainly due to the accessibility of apps and the diffusion of the mobile phone (Kumar, 2013). MHealth apps can be used as a powerful tool for health prevention and self-management. In fact, the characteristics and technical functionality of mApps - ubiquitous, portable and capable of advanced computational capacity - permit us to explore new opportunities to change patients' health behaviour (Cafazzo et al., 2012; Ben-Zeev et al., 2013). The diffusion of mobile applications in the health sector is a particular event that, in a short period of time, has completely modified not only the relationship between medical professional and patients but also habits and patients' lifestyles, so it is very difficult to imagine living without it (Kaplan, 2012). This digital technology in the COVID era, if deployed correctly, could substantively contribute to containing and reversing the spread of the virus. Knowledge sharing and the community created among patients, medical doctors and public authorities through mobile technology can play a prominent role in improving our quality of life (social support and personal interactions) and modifying contact tracing and symptom checking. In this COVID-time, $71 \mathrm{mApps}$ were specifically developed (on different platforms and in various stores) to support self-management, contact tracing, symptom checking differently for quality, content and functionality.

More research is needed to determine their optimal capabilities and evaluate their utility, which can be done by determining the clinical benefit. MHealth can offer a wide range of smart 
modalities that allows patients to interact directly with health professionals and systems to obtain help in real-time and feedback along the continuum of care from prevention to diagnosis, and treatment and monitoring. Specifically, the apps offer a particular value for health treatment in situations where continuous interaction is important. App developers get deeper insights on critical determinants that govern the adoption of mApps. It is initially important to consider antecedents like perceived usefulness, ease to use, enjoyment and cues to action when designing the user interface and application features to establish a solid foundation for a health app. The developed research allowed us to underline the ease and practical use of the mApps in supporting Health Systems. However, the sensitivity of the subject requires greater attention to their practical use. Hundreds of mobile applications are available to users/patients, and they are rapidly changing on a daily basis. Our results indicate, however, that the quality and content of these applications vary greatly, suggesting that while some users consider that certain applications are of high quality, many others are sub-optimal and in need of improvement. Technical malfunctions may be one of the primary reasons for negative reviews (comments users). Despite these limitations, users find the applications to be tremendously beneficial.

Some limitations appear in this research paper. Firstly, applications are created and fail daily, and their dynamic nature gives this work contingent value. In the future, the situation could change. Secondly, for their analysis, the authors used the available information presented in the full descriptions of each application regarding functions and capabilities. It is possible that applications had features that were not listed in the description or, alternatively, advertised features that were not present or functional in the actual product. The analysis used comments and ratings on technical functionality; users who provide reviews may differ systematically from users who do not so. In addition, the language could be an obstacle to the diffusion of the mApp and understanding the phenomenon at the international level. In any case, the results can provide information on the features that are currently available on the mobile applications. Similarly, findings can provide valuable guidance to clinicians, patients and public health authorities by considering the use of mobile applications. On these premises, it is essential to ensure that patients use well-functioning applications that fulfil their unique needs for health self-management.

Another important problem regards users' privacy and security while using mApps.

As a result, the existence of a privacy policy is an important baseline standard to know why, where, and how personal details will be collected, used, shared and protected (Sunyaev, 2015). Health-related apps, in particular, are dedicated for tracking, recording and managing users' Personal Health Information (PHI) of users. PHI is extremely sensitive and needs to be highly protected through robust security and confidentiality mechanisms, such as encryption and authentication methods. Alternatively, without appropriate safeguards, the use of mApps could have a significantly negative effect on privacy and individual rights. This paper aims to help strengthen the link between ICT and healthcare. The use of mApps in healthcare can represent a new way for patients to approach the healthcare world. Therefore, this research has highlighted some interesting elements that can contribute to the efficient use of technology in the healthcare sector. These document aims to contribute both theoretically and practically onto the issue of the use of new technologies in the health sector. The results of this study provide implications for future research on the role and impact of innovation in healthcare. In fact, it was possible to test new tools that can be used in organisations to lead to a framework of high practical relevance. The originality of this study offers several innovative profiles. In 
fact, in fact improving patients' relationships with health technology is a process that involves multiple considerations in the field of knowledge management.

\section{Keywords}

healthcare; knowledge management; knowledge sharing; ICT; mobile Application (mApp); COVID-19

\section{References}

Atinaf, M., and Garfield, M. (2015), Design and Development of a Community-based mHealth Knowledge Sharing System.

Ben-Zeev, D., Kaiser, S. M., Brenner, C. J., Begale, M., Duffecy, J., and Mohr, D. C. (2013), Development and usability testing of FOCUS: A smartphone system for selfmanagement of schizophrenia. Psychiatric rehabilitation journal, 36(4), 289.

Cafazzo, J. A., Casselman, M., Hamming, N., Katzman, D. K., and Palmert, M. R. (2012), Design of an mHealth app for the self-management of adolescent type 1 diabetes: a pilot study. Journal of medical Internet research, 14(3), e70.

Chesbrough, H. W. (2003), Open innovation: The new imperative for creating and profiting from technology. Harvard Business Press.

Choi, G., Nam, C., Kim, S., Jung, H. J., and Lee, C. H. (2020), Where does knowledge-sharing motivation come from? The case of third-party developer in mobile platforms. Journal of Knowledge Management.

Davenport, T. H., and Prusak, L. (1998), Working knowledge: How organizations manage what they know. Harvard Business Press.

Davis, T. L., DiClemente, R., and Prietula, M. (2016), Taking mHealth forward: examining the core characteristics. JMIR mHealth and uHealth, 4(3), e97.

Dennison, L., Morrison, L., Conway, G., and Yardley, L. (2013), Opportunities and challenges for smartphone applications in supporting health behavior change: qualitative study. Journal of medical Internet research, 15(4), e86.

eHealth Network (2020), Mobile applications to support contact tracing in the EU's fight against COVID-19 Brussels, Belgium. Online at https://ec.europa.eu/health/sites/health/files/ehealth/docs/COVID-19_apps_en.pdf accessed 15 April 2020.

Eisenhardt, K. M. (1989), Building theories from case study research. Academy of management review, 14(4), 532-550.

Eze, E., Gleasure, R., and Heavin, C. (2016), Reviewing mHealth in developing countries: A stakeholder perspective. Procedia Computer Science, 100, 1024-1032.

Forgionne, G. A., and Kohli, R. (1995), Integrated MSS effects: An empirical health care investigation. Information processing and management, 31(6), 879-896.

Informatics, I. I. H. F. (2013), Patient Apps for Improved Healthcare: From Novelty to Mainstream. Report by the IMS Institute for Healthcare Informatics. Online at 
http://moodle.univille2.fr/pluginfile.php/215345/mod_resource/content/0/IIHI_Patient_ Apps_Report.pdf accessed 15 April 2020.

Istepanian, R., Laxminarayan, S., and Pattichis, C. S. (Eds.), (2007), M-health: Emerging mobile health systems. Springer Science and Business Media.

Kaplan, A. M. (2012), If you love something, let it go mobile: Mobile marketing and mobile social media $4 \times 4$. Business horizons, 55(2), 129-139.

Kogut, B., and Zander, U. (1992), Knowledge of the firm, combinative capabilities, and the replication of technology. Organization science, 3(3), 383-397.

Kozinets, R. V. (1999), E-tribalized marketing?: The strategic implications of virtual communities of consumption. European management journal, 17(3), 252-264

Kumar, S., Nilsen, W. J., Abernethy, A., Atienza, A., Patrick, K., Pavel, M., ... and Hedeker, D. (2013), Mobile health technology evaluation: the mHealth evidence workshop. American journal of preventive medicine, 45(2), 228-236.

Livingston, E., Bucher, K. (2020), Coronavirus disease 2019 (COVID-19) in Italy. Jama, 323(14), 1335-1335.

Moher, D., Liberati, A., Tetzlaff, J., Altman, D. G., and Prisma Group. (2009), Reprintpreferred reporting items for systematic reviews and meta-analyses: the PRISMA statement. Physical therapy, 89(9), 873-880.

Newsroom- Apple-. Online at https://www.apple.com/it/newsroom/2020/04/apple-andgoogle-partner-on-COVID-19-contact-tracing-technology/ accessed 15 April 2020.

Silva, B. M., Rodrigues, J. J., de la Torre Díez, I., López-Coronado, M., and Saleem, K. (2015), Mobile-health: A review of current state in 2015. Journal of biomedical informatics, 56, 265-272.

Sinkovics, R. R., and Sinkovics, N. (2016), Enhancing the foundations for theorising through bibliometric mapping. International Marketing Review.

Steinhubl, S. R., Muse, E. D., and Topol, E. J. (2015), The emerging field of mobile health. Science translational medicine, 7(283), 283rv3-283rv3.

Sunyaev, A., Dehling, T., Taylor, P. L., and Mandl, K. D. (2015), Availability and quality of mobile health app privacy policies. Journal of the American Medical Informatics Association, 22(e1), e28-e33.

Taylor, T. L. (2002), Living digitally: Embodiment in virtual worlds. In The social life of avatars (pp. 40-62), Springer, London.

Van Beveren, J. (2003), Does health care for knowledge management?. Journal of knowledge management.

World Health Organization (2011), mHealth New horizons for health through mobile technologies. Available online at http://www.who.int/goe/publications/goe_mhealth_web.pdf (last accessed: April 15, 2020),

Wu, Z., and McGoogan, J. M. (2020), Characteristics of and important lessons from the coronavirus disease 2019 (COVID-19) outbreak in China: summary of a report of 72314 cases from the Chinese Center for Disease Control and Prevention. Jama, 323(13), 12391242. 
Yin, R. K. (1994), Discovering the future of the case study. Method in evaluation research. Evaluation practice, 15(3), 283-290.

Yu, P., Wu, M. X., Yu, H., and Xiao, G. Q. (2006, June), The challenges for the adoption of mhealth. In 2006 IEEE International Conference on Service Operations and Logistics, and Informatics (pp. 181-186), IEEE.

Zhang, X., Liu, S., Deng, Z., and Chen, X. (2017), Knowledge sharing motivations in online health communities: A comparative study of health professionals and normal users. Computers in Human Behavior, 75, 797-810. 


\section{Appendix I}

Table I.1. Play Store mApps.

Source: Play Store (Android)

\begin{tabular}{|c|c|c|c|c|c|c|c|c|}
\hline & App name & Type & $\begin{array}{l}\text { Technical } \\
\text { Functionality }\end{array}$ & Description & Actor Relevant & $\begin{array}{l}\text { Territorial area } \\
\text { of reference }\end{array}$ & Download & $\begin{array}{l}\mathrm{N}^{\circ} \text { Comments } \\
\text { by users }\end{array}$ \\
\hline 1 & AllertaLOM & $\begin{array}{l}\text { Symptom } \\
\text { checking and } \\
\text { contact tracing }\end{array}$ & $\begin{array}{l}\text { Proximity technology } \\
\text { To reliably determine } \\
\text { the epidemiologically } \\
\text { targeted. } \\
\text { The information on the } \\
\text { app should be able to } \\
\text { estimate, with } \\
\text { sufficient accuracy, the } \\
\text { proximity of the } \\
\text { " contagion risk map". }\end{array}$ & $\begin{array}{l}\text { App (in } \\
\text { conjunction with } \\
\text { the Regional } \\
\text { Crisis Unit) } \\
\text { should be able to } \\
\text { record } \\
\text { symptoms day } \\
\text { by day through } \\
\text { self-diagnosis }\end{array}$ & $\begin{array}{l}\text { Public } \\
\text { Authority } \\
\text { (protezione } \\
\text { civile } \\
\text { Lombardia } \\
\text { Region) }\end{array}$ & $\begin{array}{l}\text { Local Territory } \\
\text { (Lombardia } \\
\text { Region) }\end{array}$ & $\begin{array}{l}500,000+ \\
3.1^{*}\end{array}$ & 3,104 \\
\hline
\end{tabular}

\begin{tabular}{|c|c|c|}
\hline 2 Sicilia Si Cura & $\begin{array}{l}\text { Contact tracing } \\
\text { and self- } \\
\text { diagnosis }\end{array}$ & $\begin{array}{l}\text { Proximity technology } \\
\text { To reliably determine } \\
\text { the epidemiologically } \\
\text { targeted. }\end{array}$ \\
\hline
\end{tabular}

The App should

able to record Authority

Local Territory $\quad 1,000+$.

$3.5^{*}$

30

symptoms day Sicilia Region

by day through

self-diagnosis 


\section{puntoorg}

\begin{tabular}{|c|c|c|c|c|c|c|c|c|}
\hline & App name & Type & $\begin{array}{l}\text { Technical } \\
\text { Functionality }\end{array}$ & Description & Actor Relevant & $\begin{array}{l}\text { Territorial area } \\
\text { of reference }\end{array}$ & Download & $\begin{array}{l}\mathrm{N}^{\circ} \text { Comments } \\
\text { by users }\end{array}$ \\
\hline 3 & LaziodrCOVID & $\begin{array}{l}\text { Contact tracing } \\
\text { and self- } \\
\text { diagnosis }\end{array}$ & $\begin{array}{l}\text { Proximity technology } \\
\text { To reliably determine } \\
\text { the epidemiologically } \\
\text { targeted. }\end{array}$ & $\begin{array}{l}\text { Control of the } \\
\text { level of risk. } \\
\text { Consultation of } \\
\text { statistics. } \\
\text { Sending a } \\
\text { contagion report. }\end{array}$ & Team Project & Local Territory & $\begin{array}{l}50,000+. \\
3.2^{*}\end{array}$ & 557 \\
\hline 4 & WHOinfo & $\begin{array}{l}\text { Contact } \\
\text { Tracing and } \\
\text { warning }\end{array}$ & $\begin{array}{l}\text { Proximity technology } \\
\text { Information on the } \\
\text { state of the virus and } \\
\text { better health for } \\
\text { everyone everywhere }\end{array}$ & $\begin{array}{l}\text { Control of the } \\
\text { level of risk. }\end{array}$ & $\begin{array}{l}\text { Public } \\
\text { Health } \\
\text { Authority }\end{array}$ & Total Territory & $\begin{array}{l}50,000+ \\
3.8^{*}\end{array}$ & 162 \\
\hline
\end{tabular}


puntoorg

5 SM_COVID 19
Contact tracing Proximity technology and self-

diagnosis

The App should be

able to send and receive and record

Bluetooth signals even

in the background

mode (even when the

phone is locked). The

App should be able to

estimate, with

sufficient accuracy, the

proximity between

mobile phones via

Bluetooth signals. The

App should make their

presence known

continuously by using

a temporary

anonymous ID that

permits establishing

contact with other app

users in proximity. The

App should record and

store IDs observed

from other mobile

phones in

epidemiologically

relevant proximity on

the device. App should

be able to indicate the

Public health

Authority.
Control of the

\section{level of risk.}
Consultation of
statistics.
Sending a
contagion report.
The code (QR
codes) created
ensures that
other individuals
cannot use it to
pollute the data
collected on the
server.

Team Project

Local

$10,000+$.

280

Territory

$4.0^{*}$ 
punt(Oorg

\begin{tabular}{|c|c|c|c|c|c|c|c|c|}
\hline & App name & Type & $\begin{array}{l}\text { Technical } \\
\text { Functionality }\end{array}$ & Description & Actor Relevant & $\begin{array}{l}\text { Territorial area } \\
\text { of reference }\end{array}$ & Download & $\begin{array}{l}N^{\circ} \text { Comments } \\
\text { by users }\end{array}$ \\
\hline 6 & $\begin{array}{l}\text { OpenWho } \\
\text { knowledge for } \\
\text { Health Emergencies }\end{array}$ & $\begin{array}{l}\text { Knowledge } \\
\text { transfer }\end{array}$ & $\begin{array}{l}\text { Interactive knowledge- } \\
\text { transfer platform }\end{array}$ & $\begin{array}{l}\text { Offering online } \\
\text { courses to } \\
\text { improve the } \\
\text { response to } \\
\text { health } \\
\text { emergencies }\end{array}$ & $\begin{array}{l}\text { Public } \\
\text { Health } \\
\text { Authority and } \\
\text { Team Project }\end{array}$ & Total Territory & $\begin{array}{l}500.000 \\
4.2^{*}\end{array}$ & 2173 \\
\hline 7 & COVID-19 & $\begin{array}{l}\text { Contact } \\
\text { Tracing, } \\
\text { warning and } \\
\text { self-diagnosis }\end{array}$ & $\begin{array}{l}\text { Acquisition and } \\
\text { monitoring of vital } \\
\text { parameters. } \\
\text { Subsequently sent to } \\
\text { the reference health } \\
\text { organisations }\end{array}$ & $\begin{array}{l}\text { Control of the } \\
\text { symptom level } \\
\text { (Application for } \\
\text { those in self- } \\
\text { isolation) }\end{array}$ & Team Project & $\begin{array}{l}\text { Total } \\
\text { Territory }\end{array}$ & $\begin{array}{l}10,000+. \\
2.8^{*}\end{array}$ & 119 \\
\hline
\end{tabular}

Table I.2. iTunes Store mApps.

Source: Play Store (Android)

\begin{tabular}{|c|c|c|c|c|c|c|c|c|}
\hline & App name & Type & $\begin{array}{l}\text { Technical } \\
\text { Functionality }\end{array}$ & Description & Actor Relevant & $\begin{array}{l}\text { Territorial } \\
\text { area of } \\
\text { reference }\end{array}$ & Download & $\begin{array}{l}\mathrm{N}^{\circ} \\
\text { Comments } \\
\text { by users }\end{array}$ \\
\hline 1 & COVID-19! & $\begin{array}{l}\text { Contact } \\
\text { Tracing and } \\
\text { warning }\end{array}$ & $\begin{array}{l}\text { Proximity } \\
\text { technology. } \\
\text { Information on the } \\
\text { state of the virus and } \\
\text { better health for }\end{array}$ & $\begin{array}{l}\text { App provides } \\
\text { expert } \\
\text { information about } \\
\text { the infection, how } \\
\text { to identify it and }\end{array}$ & Team project & Total territory & 54 & 16 \\
\hline
\end{tabular}




\section{puntoorg}

\begin{tabular}{|c|c|c|c|c|c|c|c|c|}
\hline & App name & Type & $\begin{array}{l}\text { Technical } \\
\text { Functionality }\end{array}$ & Description & Actor Relevant & $\begin{array}{l}\text { Territorial } \\
\text { area of } \\
\text { reference }\end{array}$ & Download & $\begin{array}{l}\mathrm{N}^{\circ} \\
\text { Comments } \\
\text { by users }\end{array}$ \\
\hline & & & $\begin{array}{l}\text { everyone } \\
\text { everywhere }\end{array}$ & $\begin{array}{l}\text { how to defend } \\
\text { yourself }\end{array}$ & & & $4.1^{*}$ & \\
\hline \multirow[t]{2}{*}{2} & \multirow{2}{*}{$\begin{array}{l}\text { Healthlynked } \\
\text { COVID-19 Tracker }\end{array}$} & \multirow{2}{*}{$\begin{array}{l}\text { Contact } \\
\text { Tracing and } \\
\text { Self-diagnosis }\end{array}$} & \multirow{2}{*}{$\begin{array}{l}\text { Proximity } \\
\text { technology } \\
\text { To reliably } \\
\text { determine the } \\
\text { epidemiologically } \\
\text { targeted. }\end{array}$} & \multirow{2}{*}{$\begin{array}{l}\text { The App should } \\
\text { be able to record } \\
\text { symptoms day by } \\
\text { day through self- } \\
\text { diagnosis }\end{array}$} & \multirow[t]{2}{*}{ Public Authority } & \multirow[t]{2}{*}{ Total territory } & 1097 & \multirow[t]{2}{*}{37} \\
\hline & & & & & & & $4.4^{*}$ & \\
\hline 3 & COVID-19 Gov Pk & $\begin{array}{l}\text { Knowledge } \\
\text { transfer }\end{array}$ & $\begin{array}{l}\text { Proximity } \\
\text { technology. } \\
\text { Information on the } \\
\text { state of the virus and } \\
\text { better health for } \\
\text { everyone } \\
\text { everywhere and } \\
\text { Interactive } \\
\text { knowledge }\end{array}$ & $\begin{array}{l}\text { The app provides } \\
\text { expert } \\
\text { information about } \\
\text { the infection and } \\
\text { offers online } \\
\text { courses to } \\
\text { improve the } \\
\text { response to health } \\
\text { emergencies }\end{array}$ & $\begin{array}{l}\text { Public Authority } \\
\text { (National } \\
\text { Information } \\
\text { Tecnology } \\
\text { board) }\end{array}$ & $\begin{array}{l}\text { Local Territory } \\
\text { (Pakistan) }\end{array}$ & $1.0^{*}$ & 0 \\
\hline 4 & Stop Codi19 CAT & $\begin{array}{l}\text { Contact } \\
\text { Tracing and } \\
\text { Self-diagnosis }\end{array}$ & $\begin{array}{l}\text { Proximity } \\
\text { technology in order } \\
\text { to reliably determine } \\
\text { the }\end{array}$ & $\begin{array}{l}\text { The app provides } \\
\text { expert } \\
\text { information about } \\
\text { the infection, how }\end{array}$ & $\begin{array}{l}\text { Public Authority } \\
\text { (Generalitat de } \\
\text { Catalunya) }\end{array}$ & $\begin{array}{l}\text { Local Territory } \\
\text { (Catalunya) }\end{array}$ & $2.5^{*}$ & 5 \\
\hline
\end{tabular}


puntOorg

\begin{tabular}{|c|c|c|c|c|c|c|c|c|}
\hline & App name & Type & $\begin{array}{l}\text { Technical } \\
\text { Functionality }\end{array}$ & Description & Actor Relevant & $\begin{array}{l}\text { Territorial } \\
\text { area of } \\
\text { reference }\end{array}$ & Download & $\begin{array}{l}\mathrm{N}^{\circ} \\
\text { Comments } \\
\text { by users }\end{array}$ \\
\hline & & & $\begin{array}{l}\text { epidemiologically } \\
\text { targeted. }\end{array}$ & $\begin{array}{l}\text { to identify it and } \\
\text { how to defend } \\
\text { yourself. }\end{array}$ & & & & \\
\hline 5 & TreCOVID19 & $\begin{array}{l}\text { Contact } \\
\text { Tracing and } \\
\text { Self-diagnosis }\end{array}$ & $\begin{array}{l}\text { Invention } \\
\text { management in the } \\
\text { region }\end{array}$ & $\begin{array}{l}\text { The app indicates } \\
\text { the measures for } \\
\text { the containment } \\
\text { of the virus and } \\
\text { the numbers to } \\
\text { contact in case of } \\
\text { need. }\end{array}$ & $\begin{array}{l}\text { Public Authority } \\
\text { ( Heath } \\
\text { Company) }\end{array}$ & $\begin{array}{l}\text { Local Territory } \\
\text { (Trentino) }\end{array}$ & \multicolumn{2}{|c|}{$\begin{array}{l}\text { The app did not receive a } \\
\text { sufficient number of ratings } \\
\text { or reviews, and an average } \\
\text { is not visible. }\end{array}$} \\
\hline 6 & $\begin{array}{l}\text { COVID19Regione } \\
\text { Sardegna }\end{array}$ & $\begin{array}{l}\text { Contact } \\
\text { Tracing and } \\
\text { Self-diagnosis }\end{array}$ & $\begin{array}{l}\text { Proximity } \\
\text { technology To } \\
\text { reliably determine } \\
\text { the } \\
\text { epidemiologically } \\
\text { targeted. }\end{array}$ & $\begin{array}{l}\text { App for self- } \\
\text { declaration of } \\
\text { arrivals and } \\
\text { departures in } \\
\text { Sardinia and } \\
\text { authorisation for } \\
\text { transport }\end{array}$ & $\begin{array}{l}\text { Public Authority } \\
\text { (Sardinia } \\
\text { Region) }\end{array}$ & $\begin{array}{l}\text { Local Territory } \\
\text { (Sardinia) }\end{array}$ & $\begin{array}{l}2 \\
4,5^{*}\end{array}$ & 0 \\
\hline 7 & $\begin{array}{l}\text { Coronavirus- } \\
\text { COVID19 }\end{array}$ & $\begin{array}{l}\text { Contact } \\
\text { Tracing and } \\
\text { warning }\end{array}$ & $\begin{array}{l}\text { Proximity } \\
\text { technology. } \\
\text { Information on the }\end{array}$ & $\begin{array}{l}\text { The app provides } \\
\text { expert } \\
\text { information about }\end{array}$ & $\begin{array}{l}\text { Public Authority } \\
\text { (Heath } \\
\text { Company) }\end{array}$ & Total Territory & \multicolumn{2}{|c|}{$\begin{array}{l}\text { The app did not receive a } \\
\text { sufficient number of ratings }\end{array}$} \\
\hline
\end{tabular}


puntOorg

\begin{tabular}{|c|c|c|c|c|c|c|c|c|}
\hline & App name & Type & $\begin{array}{l}\text { Technical } \\
\text { Functionality }\end{array}$ & Description & Actor Relevant & $\begin{array}{l}\text { Territorial } \\
\text { area of } \\
\text { reference }\end{array}$ & Download & $\begin{array}{l}\mathrm{N}^{\circ} \\
\text { Comments } \\
\text { by users }\end{array}$ \\
\hline & & & $\begin{array}{l}\text { state of the virus and } \\
\text { better health for } \\
\text { everyone } \\
\text { everywhere }\end{array}$ & $\begin{array}{l}\text { the infection, how } \\
\text { to identify it and } \\
\text { how to defend } \\
\text { yourself. }\end{array}$ & & & \multicolumn{2}{|c|}{$\begin{array}{l}\text { or reviews, and an average } \\
\text { is not visible. }\end{array}$} \\
\hline 8 & Coronavirus- SUS & $\begin{array}{l}\text { Contact tracing } \\
\text { and self- } \\
\text { diagnosis }\end{array}$ & $\begin{array}{l}\text { Proximity } \\
\text { technology. To } \\
\text { reliably determine } \\
\text { the } \\
\text { epidemiologically } \\
\text { targeted. }\end{array}$ & $\begin{array}{l}\text { Control of the } \\
\text { level of risk. } \\
\text { Consultation of } \\
\text { statistics. Sending } \\
\text { a contagion report }\end{array}$ & $\begin{array}{l}\text { Public Authority } \\
\text { ( Government of } \\
\text { Brazil) }\end{array}$ & $\begin{array}{l}\text { Local Territory } \\
\text { (Brazil) }\end{array}$ & $3.0^{*}$ & 4 \\
\hline 9 & $\begin{array}{l}\text { patientMpower for } \\
\text { COVID-19 }\end{array}$ & $\begin{array}{l}\text { Contact tracing } \\
\text { and self- } \\
\text { diagnosis }\end{array}$ & $\begin{array}{l}\text { Proximity } \\
\text { technology To } \\
\text { reliably determine } \\
\text { the } \\
\text { epidemiologically } \\
\text { targeted. }\end{array}$ & $\begin{array}{l}\text { The app will } \\
\text { allow you to } \\
\text { monitor } \\
\text { symptoms and } \\
\text { health } \\
\text { information in } \\
\text { self-isolation. }\end{array}$ & Tem Project & $\begin{array}{l}\text { Local Territory } \\
\text { (Ireland) }\end{array}$ & \multicolumn{2}{|c|}{$\begin{array}{l}\text { The app did not receive a } \\
\text { sufficient number of ratings } \\
\text { or reviews, and an average } \\
\text { is not visible. }\end{array}$} \\
\hline 10 & $\begin{array}{l}\text { Coronavirus } \\
\text { COVID Trancker }\end{array}$ & $\begin{array}{l}\text { Contact } \\
\text { Tracing and } \\
\text { warning }\end{array}$ & $\begin{array}{l}\text { Proximity } \\
\text { technology. } \\
\text { Information on the } \\
\text { state of the virus and } \\
\text { better health for }\end{array}$ & $\begin{array}{l}\text { The app fights } \\
\text { COVID-19 by } \\
\text { tracking global } \\
\text { evolution and } \\
\text { staying up to date }\end{array}$ & Team project & Total Territory & \multicolumn{2}{|c|}{$\begin{array}{l}\text { The app did not receive a } \\
\text { sufficient number of ratings } \\
\text { or reviews, and an average } \\
\text { is not visible }\end{array}$} \\
\hline
\end{tabular}


puntOorg

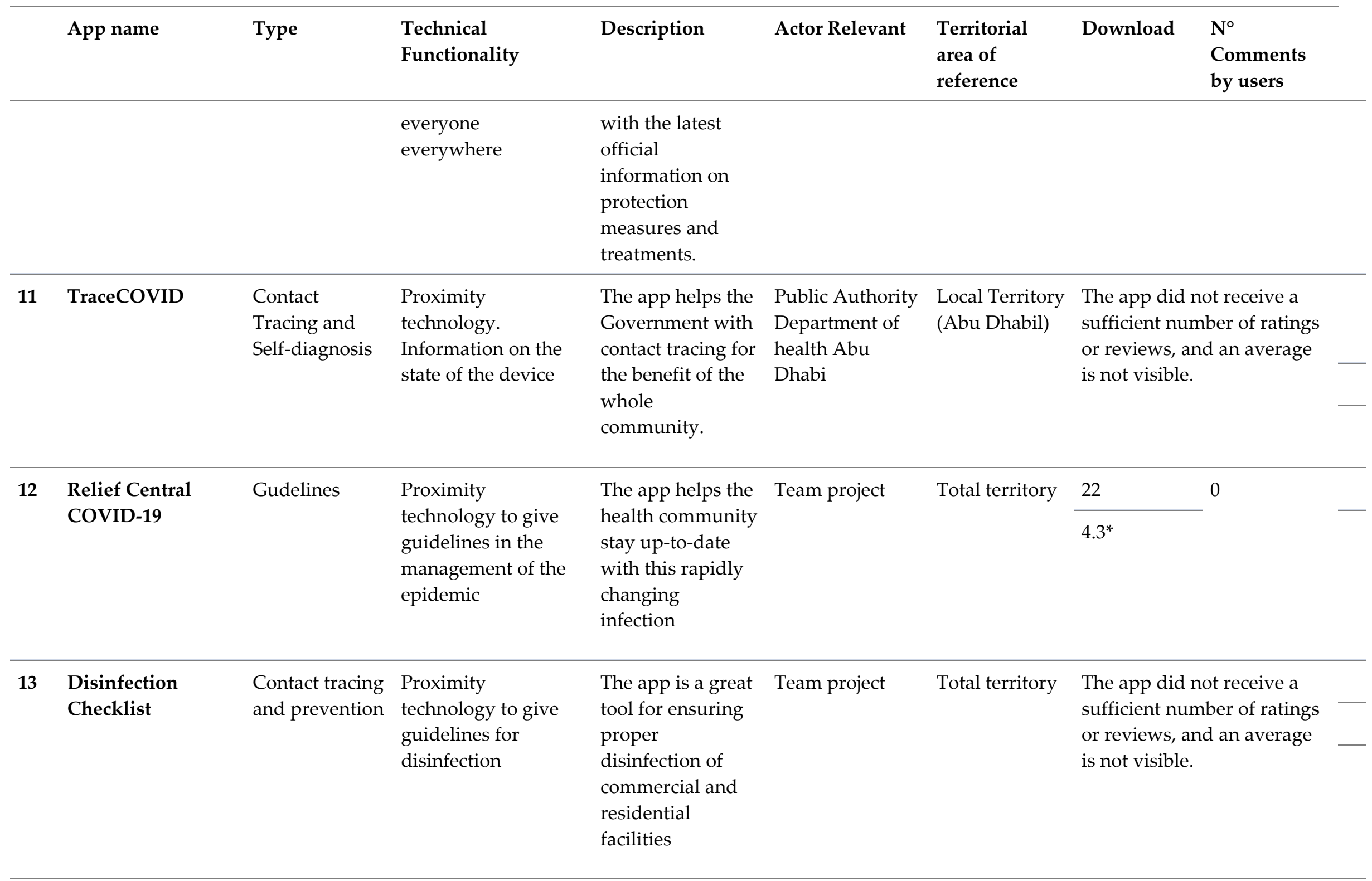


punt(Oorg

\begin{tabular}{|c|c|c|c|c|c|c|c|c|}
\hline & App name & Type & $\begin{array}{l}\text { Technical } \\
\text { Functionality }\end{array}$ & Description & Actor Relevant & $\begin{array}{l}\text { Territorial } \\
\text { area of } \\
\text { reference }\end{array}$ & Download & $\begin{array}{l}\mathrm{N}^{\circ} \\
\text { Comments } \\
\text { by users }\end{array}$ \\
\hline 14 & COVID-19 News & $\begin{array}{l}\text { Contact } \\
\text { Tracing and } \\
\text { Self-diagnosis }\end{array}$ & $\begin{array}{l}\text { Proximity } \\
\text { technology. } \\
\text { Information on the } \\
\text { state of the device }\end{array}$ & $\begin{array}{l}\text { all the news } \\
\text { related to the } \\
\text { pandemic }\end{array}$ & Team project & Local Territory & \multicolumn{2}{|c|}{$\begin{array}{l}\text { The app did not receive a } \\
\text { sufficient number of ratings } \\
\text { or reviews, and an average } \\
\text { is not visible. }\end{array}$} \\
\hline 15 & COVID -19 AR & $\begin{array}{l}\text { Contact tracing } \\
\text { and prevention }\end{array}$ & $\begin{array}{l}\text { Proximity } \\
\text { technology To } \\
\text { reliably determine } \\
\text { the } \\
\text { epidemiologically } \\
\text { targeted. }\end{array}$ & $\begin{array}{l}\text { The app will } \\
\text { provide health } \\
\text { information for } \\
\text { prevention }\end{array}$ & $\begin{array}{l}\text { Public Authority } \\
\text { (Government } \\
\text { Argentina) }\end{array}$ & $\begin{array}{l}\text { Local Territory } \\
\text { (Argentina) }\end{array}$ & \multicolumn{2}{|c|}{$\begin{array}{l}\text { The app did not receive a } \\
\text { sufficient number of ratings } \\
\text { or reviews, and an average } \\
\text { is not visible. }\end{array}$} \\
\hline 16 & Castor COVID-19 & $\begin{array}{l}\text { Contact tracing } \\
\text { and self- } \\
\text { diagnosis }\end{array}$ & $\begin{array}{l}\text { Proximity } \\
\text { technology To } \\
\text { reliably determine } \\
\text { the } \\
\text { epidemiologically } \\
\text { targeted. }\end{array}$ & $\begin{array}{l}\text { The app will } \\
\text { allow you to } \\
\text { monitor } \\
\text { symptoms, which } \\
\text { can be monitored } \\
\text { by trained } \\
\text { healthcare } \\
\text { professionals } \\
\text { through real-time } \\
\text { dashboards }\end{array}$ & $\begin{array}{l}\text { Public Authority } \\
\text { (Healthy } \\
\text { Ageing) }\end{array}$ & Total territory & \multicolumn{2}{|c|}{$\begin{array}{l}\text { The app did not receive a } \\
\text { sufficient number of ratings } \\
\text { or reviews, and an average } \\
\text { is not visible. }\end{array}$} \\
\hline 17 & Cova Punjab & & & & Public Authority & & 3 & 0 \\
\hline
\end{tabular}




\begin{tabular}{|c|c|c|c|c|c|c|c|c|}
\hline & App name & Type & $\begin{array}{l}\text { Technical } \\
\text { Functionality }\end{array}$ & Description & Actor Relevant & $\begin{array}{l}\text { Territorial } \\
\text { area of } \\
\text { reference }\end{array}$ & Download & $\begin{array}{l}\mathrm{N}^{\circ} \\
\text { Comments } \\
\text { by users }\end{array}$ \\
\hline & & $\begin{array}{l}\text { Contact } \\
\text { Tracing and } \\
\text { information }\end{array}$ & $\begin{array}{l}\text { Proximity } \\
\text { technology To } \\
\text { reliably determine } \\
\text { the } \\
\text { epidemiologically } \\
\text { targeted. }\end{array}$ & $\begin{array}{l}\text { The app provides } \\
\text { citizens with } \\
\text { preventive care } \\
\text { information and } \\
\text { other government } \\
\text { advisories. }\end{array}$ & $\begin{array}{l}\text { (Government } \\
\text { Punjab) }\end{array}$ & $\begin{array}{l}\text { Local Territory } \\
\text { (India) }\end{array}$ & $5^{*}$ & \\
\hline 18 & $\begin{array}{l}\text { Covive: your } \\
\text { COVID-19 app }\end{array}$ & $\begin{array}{l}\text { Symptom } \\
\text { checking and } \\
\text { contact tracing }\end{array}$ & $\begin{array}{l}\text { Proximity } \\
\text { technology To } \\
\text { reliably determine } \\
\text { the } \\
\text { epidemiologically } \\
\text { targeted. }\end{array}$ & $\begin{array}{l}\text { The app guides } \\
\text { you in evaluating } \\
\text { the probability of } \\
\text { contracting } \\
\text { COVID-19 and } \\
\text { helps you monitor } \\
\text { your symptoms }\end{array}$ & Team project & Total territory & $\frac{6}{5^{*}}$ & 0 \\
\hline 19 & SOS Coronavirus & $\begin{array}{l}\text { Contact } \\
\text { Tracing and } \\
\text { information }\end{array}$ & $\begin{array}{l}\text { Proximity } \\
\text { technology To } \\
\text { reliably determine } \\
\text { the } \\
\text { epidemiologically } \\
\text { targeted. }\end{array}$ & $\begin{array}{l}\text { The app raises } \\
\text { awareness of the } \\
\text { damage from } \\
\text { COVID-19 and } \\
\text { manages } \\
\text { suspected cases. }\end{array}$ & $\begin{array}{l}\text { Public Authority } \\
\text { (Ministry of } \\
\text { Health and } \\
\text { Social Affairs) }\end{array}$ & Total territory & \multicolumn{2}{|c|}{$\begin{array}{l}\text { The app did not receive a } \\
\text { sufficient number of ratings } \\
\text { or reviews, and an average } \\
\text { is not visible. }\end{array}$} \\
\hline 20 & COVID-19 UAE & $\begin{array}{l}\text { Contact } \\
\text { Tracing and } \\
\text { Self-diagnosis }\end{array}$ & $\begin{array}{l}\text { Proximity } \\
\text { technology To } \\
\text { reliably determine } \\
\text { the }\end{array}$ & $\begin{array}{l}\text { The app provides } \\
\text { you with real- } \\
\text { time Coronavirus } \\
\text { cases information }\end{array}$ & $\begin{array}{l}\text { Public Authority } \\
\text { (Ministry of } \\
\text { Health UAE) }\end{array}$ & Total territory & \multicolumn{2}{|c|}{$\begin{array}{l}\text { The app did not receive a } \\
\text { sufficient number of ratings } \\
\text { or reviews, and an average } \\
\text { is not visible. }\end{array}$} \\
\hline
\end{tabular}


puntOorg

\begin{tabular}{|c|c|c|c|c|c|c|c|c|}
\hline & App name & Type & $\begin{array}{l}\text { Technical } \\
\text { Functionality }\end{array}$ & Description & Actor Relevant & $\begin{array}{l}\text { Territorial } \\
\text { area of } \\
\text { reference }\end{array}$ & Download & $\begin{array}{l}\mathrm{N}^{\circ} \\
\text { Comments } \\
\text { by users }\end{array}$ \\
\hline & & & $\begin{array}{l}\text { epidemiologically } \\
\text { targeted. }\end{array}$ & & & & & \\
\hline 21 & $\begin{array}{l}\text { COVID -19 } \\
\text { Armenia }\end{array}$ & $\begin{array}{l}\text { Contact } \\
\text { Tracing and } \\
\text { warning }\end{array}$ & $\begin{array}{l}\text { Proximity } \\
\text { technology } \\
\text { Information on the } \\
\text { state of the virus and } \\
\text { better health for } \\
\text { everyone } \\
\text { everywhere }\end{array}$ & $\begin{array}{l}\text { The app will help } \\
\text { you stay up to } \\
\text { date with the } \\
\text { latest official } \\
\text { news about } \\
\text { COVID-19 }\end{array}$ & $\begin{array}{l}\text { Public Authority } \\
\text { (Government } \\
\text { Armenia) }\end{array}$ & Local Territory & \multicolumn{2}{|c|}{$\begin{array}{l}\text { the app did not receive a } \\
\text { sufficient number of ratings } \\
\text { or reviews, and an average } \\
\text { is not visible. }\end{array}$} \\
\hline 22 & $\begin{array}{l}\text { COVID-19 } \\
\text { learning Platform }\end{array}$ & $\begin{array}{l}\text { Knowledge } \\
\text { transfer }\end{array}$ & $\begin{array}{l}\text { Interactive } \\
\text { knowledge-transfer } \\
\text { platform }\end{array}$ & $\begin{array}{l}\text { Learning platform } \\
\text { is an online web } \\
\text { and mobile based } \\
\text { large-scale } \\
\text { training solution } \\
\text { developed by } \\
\text { combining } \\
\text { empower's } \\
\text { digital, products } \\
\text { and services, } \\
\text { including } \\
\text { learning platform, } \\
\text { impact } \\
\text { measurement } \\
\text { tools and e- } \\
\text { learning content }\end{array}$ & Team project & Total territory & \multicolumn{2}{|c|}{$\begin{array}{l}\text { The app did not receive a } \\
\text { sufficient number of ratings } \\
\text { or reviews, and an average } \\
\text { is not visible. }\end{array}$} \\
\hline
\end{tabular}




\begin{tabular}{|c|c|c|c|c|c|c|c|c|}
\hline & App name & Type & $\begin{array}{l}\text { Technical } \\
\text { Functionality }\end{array}$ & Description & Actor Relevant & $\begin{array}{l}\text { Territorial } \\
\text { area of } \\
\text { reference }\end{array}$ & Download & $\begin{array}{l}\mathrm{N}^{\circ} \\
\text { Comments } \\
\text { by users }\end{array}$ \\
\hline 23 & $\begin{array}{l}\text { COVID-19 } \\
\text { Cuernavaca }\end{array}$ & $\begin{array}{l}\text { Contact } \\
\text { Tracing and } \\
\text { information }\end{array}$ & $\begin{array}{l}\text { Proximity } \\
\text { technology To } \\
\text { reliably determine } \\
\text { the } \\
\text { epidemiologically } \\
\text { targeted. }\end{array}$ & $\begin{array}{l}\text { The app provides } \\
\text { citizens with } \\
\text { preventive care } \\
\text { information }\end{array}$ & Team project & Local Territory & \multicolumn{2}{|c|}{$\begin{array}{l}\text { The app did not receive a } \\
\text { sufficient number of ratings } \\
\text { or reviews, and an average } \\
\text { is not visible. }\end{array}$} \\
\hline 24 & CDC & $\begin{array}{l}\text { Contact } \\
\text { Tracing and } \\
\text { information }\end{array}$ & $\begin{array}{l}\text { Proximity } \\
\text { technology To } \\
\text { reliably determine } \\
\text { the } \\
\text { epidemiologically } \\
\text { targeted. }\end{array}$ & $\begin{array}{l}\text { The app ensures } \\
\text { that you're } \\
\text { getting the most } \\
\text { up to date health } \\
\text { information }\end{array}$ & Team project & Local Territory & $\begin{array}{l}4 \\
2 * \\
\end{array}$ & 1 \\
\hline 25 & MyAus COVID-19 & $\begin{array}{l}\text { Contact } \\
\text { Tracing and } \\
\text { information }\end{array}$ & $\begin{array}{l}\text { Proximity } \\
\text { technology To } \\
\text { reliably determine } \\
\text { the } \\
\text { epidemiologically } \\
\text { targeted. }\end{array}$ & $\begin{array}{l}\text { A resource for } \\
\text { information about } \\
\text { COVID-19 and } \\
\text { how it impacts } \\
\text { you }\end{array}$ & Team project & $\begin{array}{l}\text { Local Territory } \\
\text { (Australia) }\end{array}$ & \multicolumn{2}{|c|}{$\begin{array}{l}\text { The app did not receive a } \\
\text { sufficient number of ratings } \\
\text { or reviews, and an average } \\
\text { is not visible. }\end{array}$} \\
\hline 26 & $\begin{array}{l}\text { Coronavirus } \\
\text { Australia }\end{array}$ & $\begin{array}{l}\text { Contact } \\
\text { Tracing and } \\
\text { information }\end{array}$ & $\begin{array}{l}\text { Proximity } \\
\text { technology To } \\
\text { reliably determine } \\
\text { the } \\
\text { epidemiologically } \\
\text { targeted. }\end{array}$ & $\begin{array}{l}\text { The app provides } \\
\text { citizens with } \\
\text { preventive care } \\
\text { information }\end{array}$ & Team project & $\begin{array}{l}\text { Local Territory } \\
\text { (Australia) }\end{array}$ & \multicolumn{2}{|c|}{$\begin{array}{l}\text { The app did not receive a } \\
\text { sufficient number of ratings } \\
\text { or reviews, and an average } \\
\text { is not visible. }\end{array}$} \\
\hline 27 & & & & & Team project & & & \\
\hline
\end{tabular}


puntOorg

\begin{tabular}{|c|c|c|c|c|c|c|c|c|}
\hline & App name & Type & $\begin{array}{l}\text { Technical } \\
\text { Functionality }\end{array}$ & Description & Actor Relevant & $\begin{array}{l}\text { Territorial } \\
\text { area of } \\
\text { reference }\end{array}$ & Download & $\begin{array}{l}\mathrm{N}^{\circ} \\
\text { Comments } \\
\text { by users }\end{array}$ \\
\hline & $\begin{array}{l}\text { BMC Combat } \\
\text { COVID }\end{array}$ & $\begin{array}{l}\text { Contact } \\
\text { Tracing and } \\
\text { Self-diagnosis }\end{array}$ & $\begin{array}{l}\text { Proximity } \\
\text { technology } \\
\text { Information on the } \\
\text { state of the virus and } \\
\text { better health for } \\
\text { everyone } \\
\text { everywhere }\end{array}$ & $\begin{array}{l}\text { The app marks } \\
\text { you transition } \\
\text { from self } \\
\text { quarantine, this } \\
\text { will help us track } \\
\text { your health } \\
\text { progress and } \\
\text { contain the } \\
\text { spread of this } \\
\text { virus }\end{array}$ & & $\begin{array}{l}\text { Local Territory } \\
\text { (Mumbai) }\end{array}$ & \multicolumn{2}{|c|}{$\begin{array}{l}\text { The app did not receive a } \\
\text { sufficient number of ratings } \\
\text { or reviews, and an average } \\
\text { is not visible. }\end{array}$} \\
\hline 28 & $\begin{array}{l}\text { Patientsphere for } \\
\text { COVID } 19\end{array}$ & $\begin{array}{l}\text { Contact } \\
\text { Tracing, } \\
\text { warning and } \\
\text { self-diagnosis }\end{array}$ & $\begin{array}{l}\text { Acquisition and } \\
\text { monitoring of vital } \\
\text { parameters. }\end{array}$ & $\begin{array}{l}\text { The app tracks } \\
\text { symptoms and } \\
\text { helps you } \\
\text { communicate } \\
\text { with your doctor } \\
\text { and help them to } \\
\text { diagnose the } \\
\text { disease } \\
\text { accurately. }\end{array}$ & Team project & Total territory & \multicolumn{2}{|c|}{$\begin{array}{l}\text { The app did not receive a } \\
\text { sufficient number of ratings } \\
\text { or reviews, and an average } \\
\text { is not visible. }\end{array}$} \\
\hline \multirow[t]{2}{*}{29} & \multirow[t]{2}{*}{ HowweFeel } & \multirow{2}{*}{$\begin{array}{l}\text { Contact } \\
\text { Tracing and } \\
\text { information }\end{array}$} & \multirow{2}{*}{$\begin{array}{l}\text { Proximity } \\
\text { technology To } \\
\text { reliably determine } \\
\text { the } \\
\text { epidemiologically } \\
\text { targeted. }\end{array}$} & \multirow{2}{*}{$\begin{array}{l}\text { The app is the } \\
\text { global community } \\
\text { to fight the } \\
\text { COVID-19 }\end{array}$} & \multirow[t]{2}{*}{ Team project } & \multirow[t]{2}{*}{ Total territory } & 2 & 0 \\
\hline & & & & & & & $5^{*}$ & \\
\hline 30 & Bolivia Segura & & & & Team project & & 1 & 0 \\
\hline
\end{tabular}


puntOorg

\begin{tabular}{|c|c|c|c|c|c|c|c|c|}
\hline & App name & Type & $\begin{array}{l}\text { Technical } \\
\text { Functionality }\end{array}$ & Description & Actor Relevant & $\begin{array}{l}\text { Territorial } \\
\text { area of } \\
\text { reference }\end{array}$ & Download & $\begin{array}{l}\mathrm{N}^{\circ} \\
\text { Comments } \\
\text { by users }\end{array}$ \\
\hline & & $\begin{array}{l}\text { Contact } \\
\text { Tracing and } \\
\text { information }\end{array}$ & $\begin{array}{l}\text { Proximity } \\
\text { technology To } \\
\text { reliably determine } \\
\text { the } \\
\text { epidemiologically } \\
\text { targeted. }\end{array}$ & $\begin{array}{l}\text { The app gives } \\
\text { official } \\
\text { information about } \\
\text { the COVID-19 }\end{array}$ & & $\begin{array}{l}\text { Local Territory } \\
\text { (Bolivia) }\end{array}$ & $5^{*}$ & \\
\hline 31 & CoronaFacts & $\begin{array}{l}\text { Contact } \\
\text { Tracing and } \\
\text { information }\end{array}$ & $\begin{array}{l}\text { "Proximity } \\
\text { technology } \\
\text { Information on the } \\
\text { state of the virus and } \\
\text { better health for } \\
\text { everyone } \\
\text { everywhere" }\end{array}$ & $\begin{array}{l}\text { Created by a } \\
\text { physician, the app } \\
\text { provides a trusted } \\
\text { source of } \\
\text { information on } \\
\text { the spread of } \\
\text { COVID-19 } \\
\text { globally }\end{array}$ & Team project & Total territory & \multicolumn{2}{|c|}{$\begin{array}{l}\text { The app did not receive a } \\
\text { sufficient number of ratings } \\
\text { or reviews, and an average } \\
\text { is not visible. }\end{array}$} \\
\hline 32 & $\begin{array}{l}\text { Nuahealth Video } \\
\text { Consultation }\end{array}$ & $\begin{array}{l}\text { Contact } \\
\text { Tracing and } \\
\text { information }\end{array}$ & $\begin{array}{l}\text { Proximity } \\
\text { technology To } \\
\text { reliably determine } \\
\text { the } \\
\text { epidemiologically } \\
\text { targeted }\end{array}$ & $\begin{array}{l}\text { The app is a } \\
\text { Video } \\
\text { Consultation } \\
\text { service with a } \\
\text { physician }\end{array}$ & Team project & Total territory & \multicolumn{2}{|c|}{$\begin{array}{l}\text { The app did not receive a } \\
\text { sufficient number of ratings } \\
\text { or reviews, and an average } \\
\text { is not visible. }\end{array}$} \\
\hline 33 & Sentinel Monitor & $\begin{array}{l}\text { Symptom } \\
\text { checking and } \\
\text { contact tracing }\end{array}$ & $\begin{array}{l}\text { Acquisition and } \\
\text { monitoring of vital } \\
\text { parameters. } \\
\text { Subsequently sent to } \\
\text { the reference health } \\
\text { organisations }\end{array}$ & $\begin{array}{l}\text { Control of the } \\
\text { symptom level }\end{array}$ & Team project & Total territory & \multicolumn{2}{|c|}{$\begin{array}{l}\text { The app did not receive a } \\
\text { sufficient number of ratings } \\
\text { or reviews, and an average } \\
\text { is not visible. }\end{array}$} \\
\hline
\end{tabular}




\begin{tabular}{|c|c|c|c|c|c|c|c|c|}
\hline & App name & Type & $\begin{array}{l}\text { Technical } \\
\text { Functionality }\end{array}$ & Description & Actor Relevant & $\begin{array}{l}\text { Territorial } \\
\text { area of } \\
\text { reference }\end{array}$ & Download & $\begin{array}{l}\mathrm{N}^{\circ} \\
\text { Comments } \\
\text { by users }\end{array}$ \\
\hline 34 & Tarassud & $\begin{array}{l}\text { Contact } \\
\text { Tracing and } \\
\text { information }\end{array}$ & $\begin{array}{l}\text { Proximity } \\
\text { technology To } \\
\text { reliably determine } \\
\text { the } \\
\text { epidemiologically } \\
\text { targeted }\end{array}$ & $\begin{array}{l}\text { The app gets } \\
\text { updates about the } \\
\text { virus in the } \\
\text { country }\end{array}$ & $\begin{array}{l}\text { Public Authority } \\
\text { ( Ministry of } \\
\text { health Oman) }\end{array}$ & $\begin{array}{l}\text { Local Territory } \\
\text { (Oman) }\end{array}$ & \multicolumn{2}{|c|}{$\begin{array}{l}\text { The app did not receive a } \\
\text { sufficient number of ratings } \\
\text { or reviews, and an average } \\
\text { is not visible. }\end{array}$} \\
\hline 35 & StopCOVID & $\begin{array}{l}\text { Contact } \\
\text { Tracing and } \\
\text { information }\end{array}$ & $\begin{array}{l}\text { Proximity } \\
\text { technology To } \\
\text { reliably determine } \\
\text { the } \\
\text { epidemiologically } \\
\text { targeted }\end{array}$ & $\begin{array}{l}\text { The app supports } \\
\text { the prevention } \\
\text { and spread of } \\
\text { COVID-19 } \\
\text { through contact } \\
\text { tracing. }\end{array}$ & $\begin{array}{l}\text { Public Authority } \\
\text { ( Ministry of } \\
\text { health and Social } \\
\text { Affairs) }\end{array}$ & $\begin{array}{l}\text { Local Territory } \\
\text { (Georgia) }\end{array}$ & \multicolumn{2}{|c|}{$\begin{array}{l}\text { The app did not receive a } \\
\text { sufficient number of ratings } \\
\text { or reviews, and an average } \\
\text { is not visible. }\end{array}$} \\
\hline 36 & COVID-19 Tam & $\begin{array}{l}\text { Contact } \\
\text { Tracing and } \\
\text { information }\end{array}$ & $\begin{array}{l}\text { Proximity } \\
\text { technology To } \\
\text { reliably determine } \\
\text { the } \\
\text { epidemiologically } \\
\text { targeted. }\end{array}$ & $\begin{array}{l}\text { The app gives } \\
\text { official } \\
\text { information about } \\
\text { COVID-19. }\end{array}$ & Team project & Total territory & \multicolumn{2}{|c|}{$\begin{array}{l}\text { The app did not receive a } \\
\text { sufficient number of ratings } \\
\text { or reviews, and an average } \\
\text { is not visible. }\end{array}$} \\
\hline \multirow[t]{2}{*}{37} & \multirow{2}{*}{$\begin{array}{l}\text { CoronApp- } \\
\text { Colombia }\end{array}$} & \multirow{2}{*}{$\begin{array}{l}\text { Contact } \\
\text { Tracing and } \\
\text { warning }\end{array}$} & \multirow[b]{2}{*}{$\begin{array}{l}\text { "Proximity } \\
\text { technology. } \\
\text { Information on the } \\
\text { state of the virus and } \\
\text { better health for } \\
\text { everyone } \\
\text { everywhere" }\end{array}$} & \multirow{2}{*}{$\begin{array}{l}\text { Control of the } \\
\text { level of risk. }\end{array}$} & \multirow{2}{*}{$\begin{array}{l}\text { Public Authority } \\
\text { (national health } \\
\text { Institute) }\end{array}$} & \multirow{2}{*}{$\begin{array}{l}\text { Local Territory } \\
\text { (Colombia) }\end{array}$} & 3 & 2 \\
\hline & & & & & & & $4.3^{*}$ & \\
\hline 38 & COVIDom Patient & & & & Public Authority & & & \\
\hline
\end{tabular}


punt(Oorg

\begin{tabular}{|c|c|c|c|c|c|c|c|c|}
\hline & App name & Type & $\begin{array}{l}\text { Technical } \\
\text { Functionality }\end{array}$ & Description & Actor Relevant & $\begin{array}{l}\text { Territorial } \\
\text { area of } \\
\text { reference }\end{array}$ & Download & $\begin{array}{l}\mathrm{N}^{\circ} \\
\text { Comments } \\
\text { by users }\end{array}$ \\
\hline & & $\begin{array}{l}\text { Contact } \\
\text { Tracing and } \\
\text { warning }\end{array}$ & $\begin{array}{l}\text { Acquisition and } \\
\text { monitoring of vital } \\
\text { parameters }\end{array}$ & $\begin{array}{l}\text { The app is only } \\
\text { useful for patients } \\
\text { who need to use } \\
\text { hospital services }\end{array}$ & & $\begin{array}{l}\text { Local Territory } \\
\text { (Paris) }\end{array}$ & \multicolumn{2}{|c|}{$\begin{array}{l}\text { The app did not receive a } \\
\text { sufficient number of ratings } \\
\text { or reviews, and an average } \\
\text { is not visible. }\end{array}$} \\
\hline 39 & $\begin{array}{l}\text { Assistencia } \\
\text { COVID-19 }\end{array}$ & $\begin{array}{l}\text { Contact tracing } \\
\text { and self- } \\
\text { diagnosis }\end{array}$ & $\begin{array}{l}\text { Proximity } \\
\text { technology. To } \\
\text { reliably determine } \\
\text { the } \\
\text { epidemiologically } \\
\text { targeted. }\end{array}$ & $\begin{array}{l}\text { The App should } \\
\text { be able to record } \\
\text { symptoms day by } \\
\text { day through self- } \\
\text { diagnosis }\end{array}$ & Team project & $\begin{array}{l}\text { Local Territory } \\
\text { (Guatemala) }\end{array}$ & \multicolumn{2}{|c|}{$\begin{array}{l}\text { The app did not receive a } \\
\text { sufficient number of ratings } \\
\text { or reviews, and an average } \\
\text { is not visible. }\end{array}$} \\
\hline 40 & Apollo COVID19 & $\begin{array}{l}\text { Contact } \\
\text { Tracing and } \\
\text { warning }\end{array}$ & $\begin{array}{l}\text { Acquisition and } \\
\text { monitoring of vital } \\
\text { parameters }\end{array}$ & $\begin{array}{l}\text { The app enables } \\
\text { contactless } \\
\text { screening for } \\
\text { COVID at the } \\
\text { medical frontlines }\end{array}$ & Team project & & \multicolumn{2}{|c|}{$\begin{array}{l}\text { "The app did not receive a } \\
\text { sufficient number of ratings } \\
\text { or reviews, and an average } \\
\text { is not visible." }\end{array}$} \\
\hline 41 & GVA Coronavirus & $\begin{array}{l}\text { Contact } \\
\text { Tracing and } \\
\text { warning }\end{array}$ & $\begin{array}{l}\text { Acquisition and } \\
\text { monitoring of vital } \\
\text { parameters }\end{array}$ & $\begin{array}{l}\text { The App should } \\
\text { be able to record } \\
\text { symptoms }\end{array}$ & team project & $\begin{array}{l}\text { Local Territory } \\
\text { (Valencia) }\end{array}$ & $\begin{array}{l}1 \\
5^{*} \\
\end{array}$ & 0 \\
\hline 42 & NHS24:COVID-19 & $\begin{array}{l}\text { Contact } \\
\text { Tracing and } \\
\text { warning }\end{array}$ & $\begin{array}{l}\text { Acquisition and } \\
\text { monitoring of vital } \\
\text { parameters }\end{array}$ & $\begin{array}{l}\text { The app assesses } \\
\text { symptoms }\end{array}$ & Team project & Total territory & \multicolumn{2}{|c|}{$\begin{array}{l}\text { The app did not receive a } \\
\text { sufficient number of ratings } \\
\text { or reviews, and an average } \\
\text { is not visible. }\end{array}$} \\
\hline 43 & Corona care & & & & Team project & Total territory & & \\
\hline
\end{tabular}




\begin{tabular}{|c|c|c|c|c|c|c|c|c|}
\hline & App name & Type & $\begin{array}{l}\text { Technical } \\
\text { Functionality }\end{array}$ & Description & Actor Relevant & $\begin{array}{l}\text { Territorial } \\
\text { area of } \\
\text { reference }\end{array}$ & Download & $\begin{array}{l}\mathrm{N}^{\circ} \\
\text { Comments } \\
\text { by users }\end{array}$ \\
\hline & & $\begin{array}{l}\text { Contact } \\
\text { Tracing and } \\
\text { warning }\end{array}$ & $\begin{array}{l}\text { Proximity } \\
\text { technology. To } \\
\text { reliably determine } \\
\text { the } \\
\text { epidemiologically } \\
\text { targeted. }\end{array}$ & $\begin{array}{l}\text { The app helps } \\
\text { healthcare } \\
\text { providers in their } \\
\text { research of the } \\
\text { symptoms of } \\
\text { infection }\end{array}$ & & & \multicolumn{2}{|c|}{$\begin{array}{l}\text { The app did not receive a } \\
\text { sufficient number of ratings } \\
\text { or reviews, and an average } \\
\text { is not visible. }\end{array}$} \\
\hline 44 & Canada COVID-19 & $\begin{array}{l}\text { Contact tracing } \\
\text { and self- } \\
\text { diagnosis }\end{array}$ & $\begin{array}{l}\text { Proximity } \\
\text { technology. To } \\
\text { reliably determine } \\
\text { the } \\
\text { epidemiologically } \\
\text { targeted. }\end{array}$ & $\begin{array}{l}\text { Control of the } \\
\text { level of risk. }\end{array}$ & $\begin{array}{l}\text { Public Authority } \\
\text { ( Canada) }\end{array}$ & $\begin{array}{l}\text { Local Territory } \\
\text { (Canada) }\end{array}$ & \multicolumn{2}{|c|}{$\begin{array}{l}\text { The app did not receive a } \\
\text { sufficient number of ratings } \\
\text { or reviews, and an average } \\
\text { is not visible. }\end{array}$} \\
\hline 45 & $\begin{array}{l}\text { Assistencia } \\
\text { COVID-19 }\end{array}$ & $\begin{array}{l}\text { Contact tracing } \\
\text { and self- } \\
\text { diagnosis }\end{array}$ & $\begin{array}{l}\text { Proximity } \\
\text { technology. To } \\
\text { reliably determine } \\
\text { the } \\
\text { epidemiologically } \\
\text { targeted. }\end{array}$ & $\begin{array}{l}\text { The App should } \\
\text { be able to record } \\
\text { symptoms day by } \\
\text { day through self- } \\
\text { diagnosis }\end{array}$ & $\begin{array}{l}\text { Public Authority } \\
\text { (Espana) }\end{array}$ & $\begin{array}{l}\text { Local Territory } \\
\text { (Espana) }\end{array}$ & \multicolumn{2}{|c|}{$\begin{array}{l}\text { The app did not receive a } \\
\text { sufficient number of ratings } \\
\text { or reviews, and an average } \\
\text { is not visible. }\end{array}$} \\
\hline 46 & Coronavirus UY & $\begin{array}{l}\text { Contact tracing } \\
\text { and self- } \\
\text { diagnosis }\end{array}$ & $\begin{array}{l}\text { "Proximity } \\
\text { technology. To } \\
\text { reliably determine } \\
\text { the } \\
\text { epidemiologically } \\
\text { targeted." }\end{array}$ & $\begin{array}{l}\text { The App should } \\
\text { be able to record } \\
\text { symptoms day by } \\
\text { day through self- } \\
\text { diagnosis }\end{array}$ & team project & Total territory & \multicolumn{2}{|c|}{$\begin{array}{l}\text { The app did not receive a } \\
\text { sufficient number of ratings } \\
\text { or reviews, and an average } \\
\text { is not visible. }\end{array}$} \\
\hline 47 & bewellxcel & & & & team project & Total territory & & \\
\hline
\end{tabular}




\begin{tabular}{|c|c|c|c|c|c|c|c|c|}
\hline & App name & Type & $\begin{array}{l}\text { Technical } \\
\text { Functionality }\end{array}$ & Description & Actor Relevant & $\begin{array}{l}\text { Territorial } \\
\text { area of } \\
\text { reference }\end{array}$ & Download & $\begin{array}{l}\mathrm{N}^{\circ} \\
\text { Comments } \\
\text { by users }\end{array}$ \\
\hline & & $\begin{array}{l}\text { Contact } \\
\text { Tracing and } \\
\text { warning }\end{array}$ & $\begin{array}{l}\text { Proximity } \\
\text { technology. } \\
\text { Information on the } \\
\text { state of the virus and } \\
\text { better health for } \\
\text { everyone } \\
\text { everywhere }\end{array}$ & $\begin{array}{l}\text { The app helps } \\
\text { you be more } \\
\text { informed about } \\
\text { the developing } \\
\text { pandemic. }\end{array}$ & & & \multicolumn{2}{|c|}{$\begin{array}{l}\text { The app did not receive a } \\
\text { sufficient number of ratings } \\
\text { or reviews, and an average } \\
\text { is not visible. }\end{array}$} \\
\hline 48 & $\begin{array}{l}\text { Cachoeirinha } \\
\text { ContraCoronavirus }\end{array}$ & $\begin{array}{l}\text { Contact } \\
\text { Tracing and } \\
\text { warning }\end{array}$ & $\begin{array}{l}\text { Proximity } \\
\text { technology. } \\
\text { Information on the } \\
\text { state of the virus and } \\
\text { better health for } \\
\text { everyone } \\
\text { everywhere }\end{array}$ & $\begin{array}{l}\text { The app helps } \\
\text { you be more } \\
\text { informed about } \\
\text { the developing } \\
\text { pandemic }\end{array}$ & team project & Total Territory & \multicolumn{2}{|c|}{$\begin{array}{l}\text { The app did not receive a } \\
\text { sufficient number of ratings } \\
\text { or reviews, and an average } \\
\text { is not visible. }\end{array}$} \\
\hline 49 & $\begin{array}{l}\text { GH COVID-19 } \\
\text { tracker }\end{array}$ & $\begin{array}{l}\text { Contact } \\
\text { Tracing and } \\
\text { warning }\end{array}$ & $\begin{array}{l}\text { Proximity } \\
\text { technology. To } \\
\text { reliably determine } \\
\text { the } \\
\text { epidemiologically } \\
\text { targeted. }\end{array}$ & $\begin{array}{l}\text { The app helps } \\
\text { healthcare } \\
\text { providers in their } \\
\text { research of the } \\
\text { symptoms of } \\
\text { infection }\end{array}$ & $\begin{array}{l}\text { Public Authority } \\
\text { (Ministry of } \\
\text { Communication) }\end{array}$ & Total territory & \multicolumn{2}{|c|}{$\begin{array}{l}\text { The app did not receive a } \\
\text { sufficient number of ratings } \\
\text { or reviews, and an average } \\
\text { is not visible. }\end{array}$} \\
\hline 50 & $\begin{array}{l}\text { Public Access } \\
\text { Control System }\end{array}$ & & $\begin{array}{l}\text { Proximity } \\
\text { technology. }\end{array}$ & $\begin{array}{l}\text { This app is used } \\
\text { for public access }\end{array}$ & team project & Total territory & \multicolumn{2}{|c|}{$\begin{array}{l}\text { The app did not receive a } \\
\text { sufficient number of ratings }\end{array}$} \\
\hline
\end{tabular}


punt(Oorg

\begin{tabular}{|c|c|c|c|c|c|c|c|c|}
\hline & App name & Type & $\begin{array}{l}\text { Technical } \\
\text { Functionality }\end{array}$ & Description & Actor Relevant & $\begin{array}{l}\text { Territorial } \\
\text { area of } \\
\text { reference }\end{array}$ & Download & $\begin{array}{l}\mathrm{N}^{\circ} \\
\text { Comments } \\
\text { by users }\end{array}$ \\
\hline & & $\begin{array}{l}\text { Contact } \\
\text { Tracing and } \\
\text { warning }\end{array}$ & $\begin{array}{l}\text { Information on the } \\
\text { state of the virus and } \\
\text { better health for } \\
\text { everyone }\end{array}$ & $\begin{array}{l}\text { control in the } \\
\text { Community. any } \\
\text { suspicious person } \\
\text { can be blacklisted } \\
\text { in communities } \\
\text { and public areas } \\
\text { to ensure safety } \\
\text { for everybody }\end{array}$ & & & \multicolumn{2}{|c|}{$\begin{array}{l}\text { or reviews, and an average } \\
\text { is not visible. }\end{array}$} \\
\hline 51 & $\begin{array}{l}\text { Musc COVID-19 } \\
\text { Vital Link }\end{array}$ & $\begin{array}{l}\text { Contact tracing } \\
\text { and self- } \\
\text { diagnosis }\end{array}$ & $\begin{array}{l}\text { Proximity } \\
\text { technology. To } \\
\text { reliably determine } \\
\text { the } \\
\text { epidemiologically } \\
\text { targeted. }\end{array}$ & $\begin{array}{l}\text { The App should } \\
\text { be able to record } \\
\text { symptoms day by } \\
\text { day through self- } \\
\text { diagnosis }\end{array}$ & $\begin{array}{l}\text { Public Authority } \\
\text { (Sud Carolina) }\end{array}$ & Local Territory & \multicolumn{2}{|c|}{$\begin{array}{l}\text { The app did not receive a } \\
\text { sufficient number of ratings } \\
\text { or reviews, and an average } \\
\text { is not visible. }\end{array}$} \\
\hline 52 & $\begin{array}{l}\text { BC COVID } 19 \\
\text { SUPPORT }\end{array}$ & $\begin{array}{l}\text { Contact } \\
\text { Tracing and } \\
\text { information }\end{array}$ & $\begin{array}{l}\text { Proximity } \\
\text { technology To } \\
\text { reliably determine } \\
\text { the } \\
\text { epidemiologically } \\
\text { targeted. }\end{array}$ & $\begin{array}{l}\text { The app gives } \\
\text { official } \\
\text { information about } \\
\text { COVID-19 }\end{array}$ & $\begin{array}{l}\text { Public Authority } \\
\text { (COLUMBIA) }\end{array}$ & Local Territory & \multicolumn{2}{|c|}{$\begin{array}{l}\text { The app did not receive a } \\
\text { sufficient number of ratings } \\
\text { or reviews, and an average } \\
\text { is not visible. }\end{array}$} \\
\hline 53 & OBVIO-19 & $\begin{array}{l}\text { Contact tracing } \\
\text { and self- } \\
\text { diagnosis }\end{array}$ & $\begin{array}{l}\text { Proximity } \\
\text { technology. To } \\
\text { reliably determine } \\
\text { the } \\
\text { epidemiologically } \\
\text { targeted }\end{array}$ & $\begin{array}{l}\text { The App should } \\
\text { be able to record } \\
\text { symptoms day by } \\
\text { day through self- } \\
\text { diagnosis }\end{array}$ & Team project & Total territory & \multicolumn{2}{|c|}{$\begin{array}{l}\text { The app did not receive a } \\
\text { sufficient number of ratings } \\
\text { or reviews, and an average } \\
\text { is not visible. }\end{array}$} \\
\hline
\end{tabular}




\begin{tabular}{|c|c|c|c|c|c|c|c|c|}
\hline & App name & Type & $\begin{array}{l}\text { Technical } \\
\text { Functionality }\end{array}$ & Description & Actor Relevant & $\begin{array}{l}\text { Territorial } \\
\text { area of } \\
\text { reference }\end{array}$ & Download & $\begin{array}{l}\mathrm{N}^{\circ} \\
\text { Comments } \\
\text { by users }\end{array}$ \\
\hline 54 & $\begin{array}{l}\text { Tali Symptom } \\
\text { tracker }\end{array}$ & $\begin{array}{l}\text { Contact tracing } \\
\text { and self- } \\
\text { diagnosis }\end{array}$ & $\begin{array}{l}\text { Proximity } \\
\text { technology. To } \\
\text { reliably determine } \\
\text { the } \\
\text { epidemiologically } \\
\text { targeted }\end{array}$ & $\begin{array}{l}\text { The App should } \\
\text { be able to record } \\
\text { symptoms day by } \\
\text { day through self- } \\
\text { diagnosis }\end{array}$ & team project & Total territory & \multicolumn{2}{|c|}{$\begin{array}{l}\text { The app did not receive a } \\
\text { sufficient number of ratings } \\
\text { or reviews, and an average } \\
\text { is not visible. }\end{array}$} \\
\hline 55 & cov_cl & $\begin{array}{l}\text { Contact } \\
\text { Tracing and } \\
\text { warning }\end{array}$ & $\begin{array}{l}\text { Proximity } \\
\text { technology. To } \\
\text { reliably determine } \\
\text { the } \\
\text { epidemiologically } \\
\text { targeted. }\end{array}$ & $\begin{array}{l}\text { Control of the } \\
\text { level of risk. } \\
\text { Consultation of } \\
\text { statistics. }\end{array}$ & team project & Total territory & \multicolumn{2}{|c|}{$\begin{array}{l}\text { The app did not receive a } \\
\text { sufficient number of ratings } \\
\text { or reviews, and an average } \\
\text { is not visible. }\end{array}$} \\
\hline 56 & PreMedicus ER & $\begin{array}{l}\text { Contact tracing } \\
\text { and self- } \\
\text { diagnosis }\end{array}$ & $\begin{array}{l}\text { "Proximity } \\
\text { technology. To } \\
\text { reliably determine } \\
\text { the } \\
\text { epidemiologically } \\
\text { targeted" }\end{array}$ & $\begin{array}{l}\text { The App should } \\
\text { be able to record } \\
\text { symptoms day by } \\
\text { day through self- } \\
\text { diagnosis }\end{array}$ & team project & Total territory & \multicolumn{2}{|c|}{$\begin{array}{l}\text { The app did not receive a } \\
\text { sufficient number of ratings } \\
\text { or reviews, and an average } \\
\text { is not visible. }\end{array}$} \\
\hline 57 & JamCOVID19 & $\begin{array}{l}\text { Contact tracing } \\
\text { and self- } \\
\text { diagnosis }\end{array}$ & $\begin{array}{l}\text { Proximity } \\
\text { technology. To } \\
\text { reliably determine } \\
\text { the } \\
\text { epidemiologically } \\
\text { targeted. }\end{array}$ & $\begin{array}{l}\text { Control of the } \\
\text { level of risk. } \\
\text { Consultation of } \\
\text { statistics. Sending } \\
\text { a contagion } \\
\text { report. }\end{array}$ & $\begin{array}{l}\text { Public Authority } \\
\text { (Jamaica) }\end{array}$ & Local Territory & \multicolumn{2}{|c|}{$\begin{array}{l}\text { The app did not receive a } \\
\text { sufficient number of ratings } \\
\text { or reviews, and an average } \\
\text { is not visible. }\end{array}$} \\
\hline 58 & AarogyaSetu & & & & Team project & & 3 & 0 \\
\hline
\end{tabular}


punt-Oorg

\begin{tabular}{|c|c|c|c|c|c|c|c|c|}
\hline & App name & Type & $\begin{array}{l}\text { Technical } \\
\text { Functionality }\end{array}$ & Description & Actor Relevant & $\begin{array}{l}\text { Territorial } \\
\text { area of } \\
\text { reference }\end{array}$ & Download & $\begin{array}{l}\mathrm{N}^{\circ} \\
\text { Comments } \\
\text { by users }\end{array}$ \\
\hline & & $\begin{array}{l}\text { Contact } \\
\text { Tracing and } \\
\text { information }\end{array}$ & $\begin{array}{l}\text { Proximity } \\
\text { technology To } \\
\text { reliably determine } \\
\text { the } \\
\text { epidemiologically } \\
\text { targeted }\end{array}$ & $\begin{array}{l}\text { The app is aimed } \\
\text { at augmenting the } \\
\text { initiatives of the } \\
\text { Government of } \\
\text { India for the } \\
\text { prevention } \\
\text { COVID-19 }\end{array}$ & & $\begin{array}{l}\text { Local Territory } \\
\text { (India) }\end{array}$ & $5^{*}$ & \\
\hline 59 & $\begin{array}{l}\text { Spectrum- } \\
\text { Clinicaldecisions }\end{array}$ & $\begin{array}{l}\text { Contact tracing } \\
\text { and self- } \\
\text { diagnosis }\end{array}$ & $\begin{array}{l}\text { Proximity } \\
\text { technology. To } \\
\text { reliably determine } \\
\text { the } \\
\text { epidemiologically } \\
\text { targeted. }\end{array}$ & $\begin{array}{l}\text { The app is a } \\
\text { customisable } \\
\text { clinical decisions } \\
\text { tool for infectious } \\
\text { diseases. }\end{array}$ & team project & Total territory & $\frac{2}{5^{*}}$ & 0 \\
\hline 60 & Kencor COVID 19 & $\begin{array}{l}\text { Contact } \\
\text { Tracing and } \\
\text { information }\end{array}$ & $\begin{array}{l}\text { Proximity } \\
\text { technology To } \\
\text { reliably determine } \\
\text { the } \\
\text { epidemiologically } \\
\text { targeted }\end{array}$ & $\begin{array}{l}\text { The app is a } \\
\text { Video } \\
\text { Consultation } \\
\text { service with a } \\
\text { physician. }\end{array}$ & team project & Total territory & \multicolumn{2}{|c|}{$\begin{array}{l}\text { The app did not receive a } \\
\text { sufficient number of ratings } \\
\text { or reviews, and an average } \\
\text { is not visible. }\end{array}$} \\
\hline 61 & & & & & team project & Total territory & & \\
\hline
\end{tabular}


puntOorg

\begin{tabular}{|c|c|c|c|c|c|c|c|c|}
\hline & App name & Type & $\begin{array}{l}\text { Technical } \\
\text { Functionality }\end{array}$ & Description & Actor Relevant & $\begin{array}{l}\text { Territorial } \\
\text { area of } \\
\text { reference }\end{array}$ & Download & $\begin{array}{l}\mathrm{N}^{\circ} \\
\text { Comments } \\
\text { by users }\end{array}$ \\
\hline & $\begin{array}{l}\text { Managing your } \\
\text { stress\& anxiety }\end{array}$ & $\begin{array}{l}\text { Contact } \\
\text { Tracing and } \\
\text { information }\end{array}$ & $\begin{array}{l}\text { Proximity } \\
\text { technology To } \\
\text { reliably determine } \\
\text { the } \\
\text { epidemiologically } \\
\text { targeted }\end{array}$ & $\begin{array}{l}\text { The app provides } \\
\text { information and } \\
\text { evidence-based } \\
\text { coping strategies } \\
\text { to help you } \\
\text { manage stress and } \\
\text { anxiety during } \\
\text { COVID-19. }\end{array}$ & & & \multicolumn{2}{|c|}{$\begin{array}{l}\text { The app did not receive a } \\
\text { sufficient number of ratings } \\
\text { or reviews, and an average } \\
\text { is not visible. }\end{array}$} \\
\hline 62 & $\begin{array}{l}\text { COVID-19 } \\
\text { Virginia Resources }\end{array}$ & $\begin{array}{l}\text { Contact } \\
\text { Tracing and } \\
\text { information }\end{array}$ & $\begin{array}{l}\text { Proximity } \\
\text { technology To } \\
\text { reliably determine } \\
\text { the } \\
\text { epidemiologically } \\
\text { targeted }\end{array}$ & $\begin{array}{l}\text { The app supports } \\
\text { the prevention } \\
\text { and spread of } \\
\text { COVID-19 } \\
\text { through contact } \\
\text { tracing. }\end{array}$ & $\begin{array}{l}\text { Public Authority } \\
\text { (Department of } \\
\text { Social Services) }\end{array}$ & $\begin{array}{l}\text { Local Territory } \\
\text { (Virginia) }\end{array}$ & \multicolumn{2}{|c|}{$\begin{array}{l}\text { The app did not receive a } \\
\text { sufficient number of ratings } \\
\text { or reviews, and an average } \\
\text { is not visible. }\end{array}$} \\
\hline 63 & $\begin{array}{l}\text { patientMpower for } \\
\text { COVID-19 USA }\end{array}$ & $\begin{array}{l}\text { Contact tracing } \\
\text { and self- } \\
\text { diagnosis }\end{array}$ & $\begin{array}{l}\text { Proximity } \\
\text { technology. To } \\
\text { reliably determine } \\
\text { the } \\
\text { epidemiologically } \\
\text { targeted. }\end{array}$ & $\begin{array}{l}\text { Control of the } \\
\text { level of risk. } \\
\text { Consultation of } \\
\text { statistics. } \\
\text { Sending a } \\
\text { contagion report. }\end{array}$ & team project & Total territory & \multicolumn{2}{|c|}{$\begin{array}{l}\text { The app did not receive a } \\
\text { sufficient number of ratings } \\
\text { or reviews, and an average } \\
\text { is not visible. }\end{array}$} \\
\hline 64 & $\begin{array}{l}\text { CNESST- } \\
\text { COVID19 }\end{array}$ & job security & $\begin{array}{l}\text { Proximity } \\
\text { technology }\end{array}$ & $\begin{array}{l}\text { Support the } \\
\text { enterprise }\end{array}$ & team project & Total territory & \multicolumn{2}{|c|}{$\begin{array}{l}\text { The app did not receive a } \\
\text { sufficient number of ratings } \\
\text { or reviews, and an average } \\
\text { is not visible. }\end{array}$} \\
\hline
\end{tabular}




\section{punteorg}

